\title{
Dynamic changes in physiological and biochemical properties of flue-cured tobacco of different leaf ages during flue- curing and their effects on yield and quality
}

Yanjie Chen ${ }^{1,2+}$, Ke Ren $^{1,2+}$, Xian He ${ }^{1+}$, Jiangshiqi Gong ${ }^{1,3}$, Xiaodong Hu', Jiaen Su', Yan Jin', Zhengxiong Zhao ${ }^{2}$, Yanmei Zhu' and Congming Zou ${ }^{1 *}$

\begin{abstract}
Background: The leaf age for harvesting flue-cured tobacco leaves is closely related to the quality of tobacco leaves, so an appropriate leaf age for harvesting is important for improving yield and quality of flue-cured tobacco, however, at present, there are few studies on effects of leaf age on physiological and biochemical changes during flue-curing and there is no clear standard of proper leaf ages for harvesting in production.

Results: In the Yunnan tobacco-growing area, an experiment was carried from 2016 to 2017 and different leaf ages were set. The results demonstrate that leaf age has a significant on tissue cell gap, leaf age and flue-curing stages exert significant effects on upper epidermis, palisade and spongy tissue, and leaf thickness of tobacco leaves. The thicknesses of upper and lower epidermis as well as palisade and spongy tissues at different ages show an approximately W-shaped change trend during flue-curing. With the advance of flue-curing stages, contents of starch, chlorophyll, carotenoid, and water in tobacco leaves at different leaf ages decrease, while polyphenol and malondialdehyde (MDA) contents increase. The older the leaf, the faster the chlorophyll, carotenoid, and water contents reduce, while the faster the polyphenol and MDA content rise during flue-curing. The flue-cured tobacco leaves at 116 DAT (days after transplanting) show the highest contents of total nitrogen and nicotine, followed by 123 DAT and those at 130 DAT are the lowest; however, the contents of total sugar and reducing sugar demonstrate a contrary tendency, and the starch content at 116 DAT is much lower than those in the other two treatments. The proportion of superior tobacco, average price, yield, and output value of upper tobacco leaves at different leaf ages are the highest at 123 DAT. The highest sensory evaluation score is found at 123 DAT, while that at 130 DAT is significantly lower in comparison with the other two treatments.

Conclusions: Tobacco leaves harvested at 123 DAT are mature and exhibit a low degree of membrane lipid peroxidation,
\end{abstract} moderate chemical compositions, and high economic value. 123 DAT improves availability of tobacco leaves.

Keywords: Leaf age, Curing process, Tissue structure, Physiological and biochemical change, Economic traits

\footnotetext{
* Correspondence: zoucongmingzcm@163.com

${ }^{\dagger}$ Yanjie Chen, Ke Ren and Xian He contributed equally to this work.

'Yunnan Academy of Tobacco Agricultural Sciences, 33 Yuantong Street,

Kunming, Yunnan 650021, People's Republic of China

Full list of author information is available at the end of the article
}

(c) The Author(s). 2019 Open Access This article is distributed under the terms of the Creative Commons Attribution 4.0 International License (http://creativecommons.org/licenses/by/4.0/), which permits unrestricted use, distribution, and reproduction in any medium, provided you give appropriate credit to the original author(s) and the source, provide a link to the Creative Commons license, and indicate if changes were made. The Creative Commons Public Domain Dedication waiver (http://creativecommons.org/publicdomain/zero/1.0/) applies to the data made available in this article, unless otherwise stated. 


\section{Background}

Flue-cured tobacco is an important economic crop and timely harvesting and moderate flue-curing are key to ensuring quality. Maturity is regarded as the primary quality factor for grading and is an important index used to measure tobacco quality: tobacco leaf age is one of important factors affecting maturity. Leaf age influences maturity, and further has impacts on flue-curing characteristics of tobacco leaves and yield and quality of flue-cured tobacco leaves. For tobacco, the upper leaves have high economic value but more difficult to get suitable maturity and fluecuring high-quality tobacco because the weather becomes unsuitable for its maturity later in the growing season [1]. Physical properties and chemical and physiological changes in upper tobacco leaves at different ages during flue-curing process have not been studied, so a proper leaf age of upper tobacco leaves has not been determined for harvesting and flue-curing.

Leaf age affects plant growth, and leaf structure and physical properties of plants change accordingly with changes in leaf age. Leaf structure of tobacco leaves is positively correlated with leaf age [2]. Leaves of different ages have differences in morphology and leaf thickness increases on the whole; moreover, the degree of hardening of old leaves is higher than that of young leaves [3]. The leaf structure of tobacco growing in the field increases with the extension of leaf age in a certain range, however, due to double stress of water and nutrient during flue-curing, cells of tobacco leaves dehydrate and shrink during flue-curing and appearance and leaf structure of tobacco leaves change to a significant extent [4]. Research has been conducted into the changes in leaf structure and physical properties of tobacco leaves during flue-curing, while tobacco of different leaf ages during flue-curing is rarely studied.

Leaf age also influences physiological and biochemical changes in plants, thus further affecting plant metabolism. Takuro et al. [5] showed that leaf age affects the photosynthetic rate of tobacco leaves, which further affects photosynthesis of tobacco leaves. The photosynthetic rate of young leaves is higher than that of overmature old leaves. Some research demonstrates that photosynthetic rate and nitrogen utilisation efficiency show a negative correlation with leaf age, and nitrogen content per unit leaf area decreases with the increasing leaf age [6]. The increase of peroxidase activity is a reliable index for judging maturity and senescence of plants. With increasing leaf age, peroxidase activity in tobacco leaves decreases, while the degree of lignification increases during maturation and senescence [7].

The contents of metabolites in plants vary with leaf age and young leaves are better than old ones in preventing biological and abiotic damage [8]. Hikosaka et al. [9] proposed that the nitrogen content is the highest in newly developed young leaves of grapes and decreases with increasing leaf age. With gradient changes in leaf age, a unique gradient of nitrogen contents can be formed in leaves. In addition, because old leaves are exposed to the environment with $\mathrm{CO}_{2}$ for a longer time, non-structural carbohydrate contents of old leaves are higher than those of young leaves [10]. As the leaf ages the contents of chlorophyll and soluble sugar in leaves increase, while the protein content decreases [11]. MDA content represents the aging speed of plants: with the increase of leaf age, the MDA content rises, indicating that the older the leaf, the faster the plants age [12].

Leaf age has certain influences on yield and quality of plants. With the increase of leaf age, the growth time of leaves in the field increases, so the probability of being damaged by climate or insects also rises [13]. Tobacco leaves harvested at different ages exhibit inconsistent maturity. In general, output value, the proportion of superior tobacco, and average price of flue-cured tobacco leaves in upper, middle, and lower parts increase with leaf age. These indices reach the highest when leaves are mature and gradually reduce with increasing age [14]. Furthermore, leaf age also influences flue-curing characteristics of tobacco leaves. Within a certain range, tobacco leaves become easier to flue-cure, while resistance to flue-curing worsens, with the increase of leaf age [15]. Plants harvested too early or late are more susceptible to post-harvest physiological disorders than those harvested at maturity and hence impairing product quality [16].

Physiological and biochemical changes of the upper tobacco leaves at different ages during flue-curing are still unknown and there is no quantitative standard for harvesting mature leaves at a proper age in production. To explore dynamic changes in structure and physiological and biochemical metabolism of upper tobacco leaves at different ages during flue-curing, we collected tobacco samples from seven flue-curing stages from 2016 to 2017. Based on this, metabolic changes to tobacco leaves at different ages during flue-curing and quality of flue-cured tobacco leaves were investigated, so as to propose a standard for harvesting tobacco leaves at a proper leaf age in the tobacco-growing area of Yunnan Province, China.

\section{Results \\ Effects of different leaf ages on morphological characteristics of tobacco leaves}

Table 1 shows that leaf age, year and their interaction do not have significant influences on tobacco leaf length and leaf width, but leaf age significantly affects tissue cell gap $(P<0.05)$. The leaf length, leaf width, and tissue cell gap of tobacco leaves increased with the increase of leaf age. Palisade tissue cell gaps at a leaf age of 130 DAT were significantly higher than those at leaf ages of 123 DAT and 116 DAT, while sponge tissue cell gaps in leaf at 116 DAT were significantly lower than in the other two treatments. 
Table 1 Effects of different leaf ages on morphological characteristics of tobacco leaves

\begin{tabular}{|c|c|c|c|c|c|c|}
\hline Leaf age (A) & Year $(Y)$ & DF & Leaf length $(\mathrm{cm})$ & Leaf width (cm) & Palisade tissue cell gap (\%) & Sponge tissue cell gap (\%) \\
\hline 116 DAT & 2016 & & $51.2 \mathrm{a}$ & $16.3 a$ & $9.32 \mathrm{C}$ & $17.25 b$ \\
\hline 123 DAT & & & $54.7 a$ & $17.8 \mathrm{a}$ & $20.34 b$ & $31.47 a$ \\
\hline 130 DAT & & & $55.8 \mathrm{a}$ & $17.5 \mathrm{a}$ & $29.89 a$ & $34.12 \mathrm{a}$ \\
\hline 116 DAT & 2017 & & $55.6 a$ & $18.4 a$ & $9.66 c$ & $19.60 \mathrm{~b}$ \\
\hline 123 DAT & & & $61.2 \mathrm{a}$ & $21.3 a$ & $21.81 b$ & $34.57 a$ \\
\hline 130 DAT & & & $63.7 a$ & $22.6 a$ & $28.94 a$ & $25.66 a$ \\
\hline A & & 2 & NS & NS & $<0.05$ & $<0.05$ \\
\hline Y & & 1 & NS & NS & NS & NS \\
\hline$A \times Y$ & & 2 & NS & NS & NS & NS \\
\hline
\end{tabular}

Note: Lowercase letters represent significant differences for different treatments in the same year $(P<0.05)$

Effects of different leaf ages on structure of tobacco leaves during flue-curing

Effects of different leaf ages on upper epidermis thickness of tobacco leaves during flue-curing

Table 2 shows that leaf age, stage, and interactions of leaf age, year, and stage significantly affect upper epidermis thickness $(P<0.05)$.

As shown in Fig. 1, the upper epidermis thicknesses of tobacco leaves at different ages gradually decreased during flue-curing and approximately showed a tendency to first decrease, then slightly increase, and finally decrease. In 2016, the upper epidermis thickness in 123 DAT rapidly reduced in Stages 1 to 3. The upper epidermis thickness in Stage 3 was significantly lower than that in Stage 1, while that in Stage 4 rose slightly then slowly decreased. At 130 DAT, the upper epidermis thickness gradually decreased in Stages 1 to 4, while it rose slightly in Stages 5 and 6 and then rapidly reduced after Stage 6. The upper epidermis thickness at 116 DAT rapidly decreased in Stages 3 to 6, while it rose slightly in Stages 6 and 7. In 2017, the upper epidermis thicknesses in Stages 1 to 3 in the three treatments showed a decreasing trend, and the thickness reduced slightly by 116 DAT. The thickness rapidly decreased and then slightly rose in Stages 4 to 6 at 123 DAT. Moreover, the thickness slowly decreased after Stage 4 in 116 DAT and 130 DAT.
Effects of different leaf ages on lower epidermis thickness of tobacco leaves during flue-curing

Table 2 demonstrates that year and flue-curing stage as well as their interactions significantly influence lower epidermis thickness of tobacco leaves $(P<0.05)$.

It can be seen from Fig. 2 that lower epidermis thickness gradually reduced with the advance of flue-curing. Within two years, the lower epidermis thickness at 123 DAT and 130 DAT rapidly reduced in Stages 1 to 4, while it rose slightly in Stages 4 and 5, then slowly decreased thereafter Stage 5. The decreases in Stages 1 to 4 at 123 DAT and 130 DAT in 2016 were greater than in 2017. The lower epidermis thickness at 116 DAT rose slightly before Stage 3 and then rapidly decreased in Stages 3 to 7.

\section{Effects of different leaf ages on palisade tissue thickness of tobacco leaves during flue-curing}

As displayed in Table 2, leaf age and flue-curing stage exert significant effects on palisade tissue thickness $(P<0.05)$.

As demonstrated in Fig. 3, palisade tissue thicknesses at 123 DAT and 130 DAT decreased with flue-curing in 2016, of which the thickness rapidly decreased in Stages 1 to 3 and then more slowly after Stage 4. At 116 DAT, the thickness rapidly decreased in Stages 1 to 3, then rose slightly, then slowly reduced in Stages 3 and 4. In 2017, the palisade tissue thickness in different treatments first

Table 2 Analysis of variance for the effects of the age of tobacco leaves, year, stage and their interactions on tissue structure

\begin{tabular}{|c|c|c|c|c|c|c|}
\hline Effect/contrast & DF & Upper epidermis & Lower epidermis & Palisade tissue & Spongy tissue & Leaf thickness \\
\hline & & \multicolumn{5}{|c|}{--------_Probability of a greater F-value---------- } \\
\hline Leaf age $(L)$ & 2 & 0.0049 & 0.4107 & $<.0001$ & 0.0025 & 0.0003 \\
\hline Year $(Y)$ & 1 & 0.0003 & 0.0411 & 0.2758 & 0.0533 & 0.1895 \\
\hline Stage (S) & 6 & $<.0001$ & $<.0001$ & $<.0001$ & $<.0001$ & $<.0001$ \\
\hline$L^{*} Y$ & 2 & 0.093 & 0.2566 & 0.5202 & 0.1901 & 0.1859 \\
\hline$L^{*} S$ & 12 & 0.0035 & 0.6867 & 0.0077 & 0.4023 & 0.0938 \\
\hline$Y^{*} S$ & 6 & 0.0796 & 0.015 & 0.6096 & 0.3335 & 0.2378 \\
\hline$L^{*} Y^{*} S$ & 12 & 0.0383 & 0.894 & 0.4387 & 0.3115 & 0.273 \\
\hline
\end{tabular}



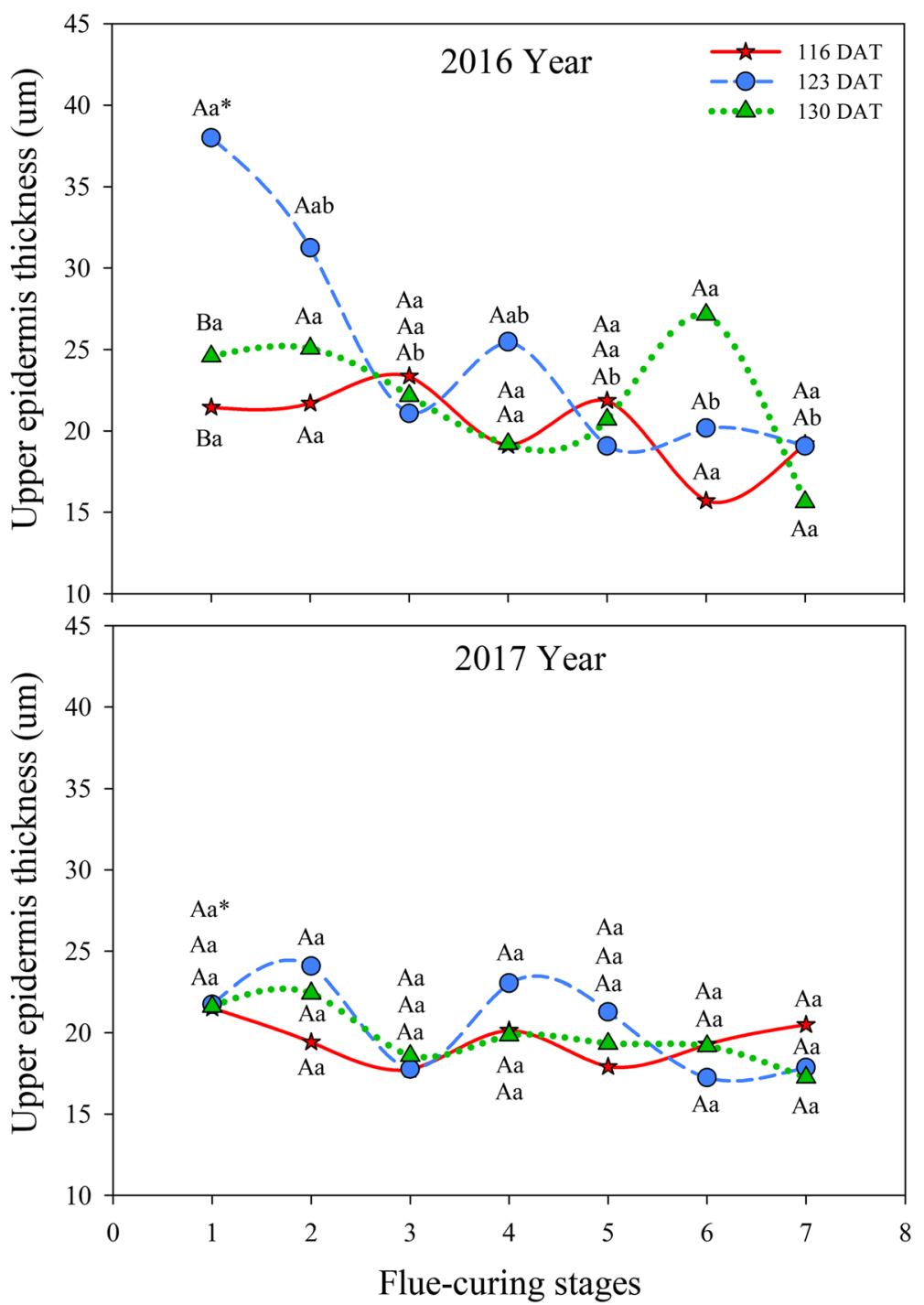

Fig. 1 Effects of interactions of different leaf ages, flue-curing stages, and years on upper epidermis thickness. Note: different capital letters indicate the significant differences between different treatments at the same stage. Different lowercase letters denote the significant differences between different stages of the same treatment. The asterisk indicates the significant differences between different years under the same treatments and same period (same below)

decreased, then increased and finally decreased in fluecuring stages: however, the thicknesses at 123 DAT and 130 DAT fell quickly in Stages 1 to 3, while slowly decreasing after a slight increase in Stages 3 to 5 , then slowly rising again in Stages 6 and 7. At 116 DAT, the thickness quickly decreased in Stages 1 and 2 and 4 and 5, then slightly increased in Stages 2 to 4 and 5 and 6.

\section{Effects of different leaf ages on spongy tissue thickness of tobacco leaves during flue-curing}

Table 2 shows that leaf age and flue-curing stage as well as their interaction show significant effects on spongy tissue thickness $(P<0.05)$.
It can be observed from Fig. 4 that the spongy tissue thicknesses in the three treatments were all reduced by flue-curing in 2016. Spongy tissue thicknesses at 123 DAT and 130 DAT rapidly decreased in Stages 1 to 3 and then slowly reduced, while the decrease at 116 DAT during flue-curing was smaller than those in the other two treatments. In 2017, the spongy tissue thicknesses in the three treatments rapidly declined in Stages 1 to 3 . The thicknesses of spongy tissue in treatments at 123 DAT and 130 DAT rose slightly, then slowly decreased in Stages 3 to 5, while that at 116 DAT were rapidly reduced after undergoing a slight increase in Stages 3 and 4, and then slowly increased again in Stages 5 and 6. 

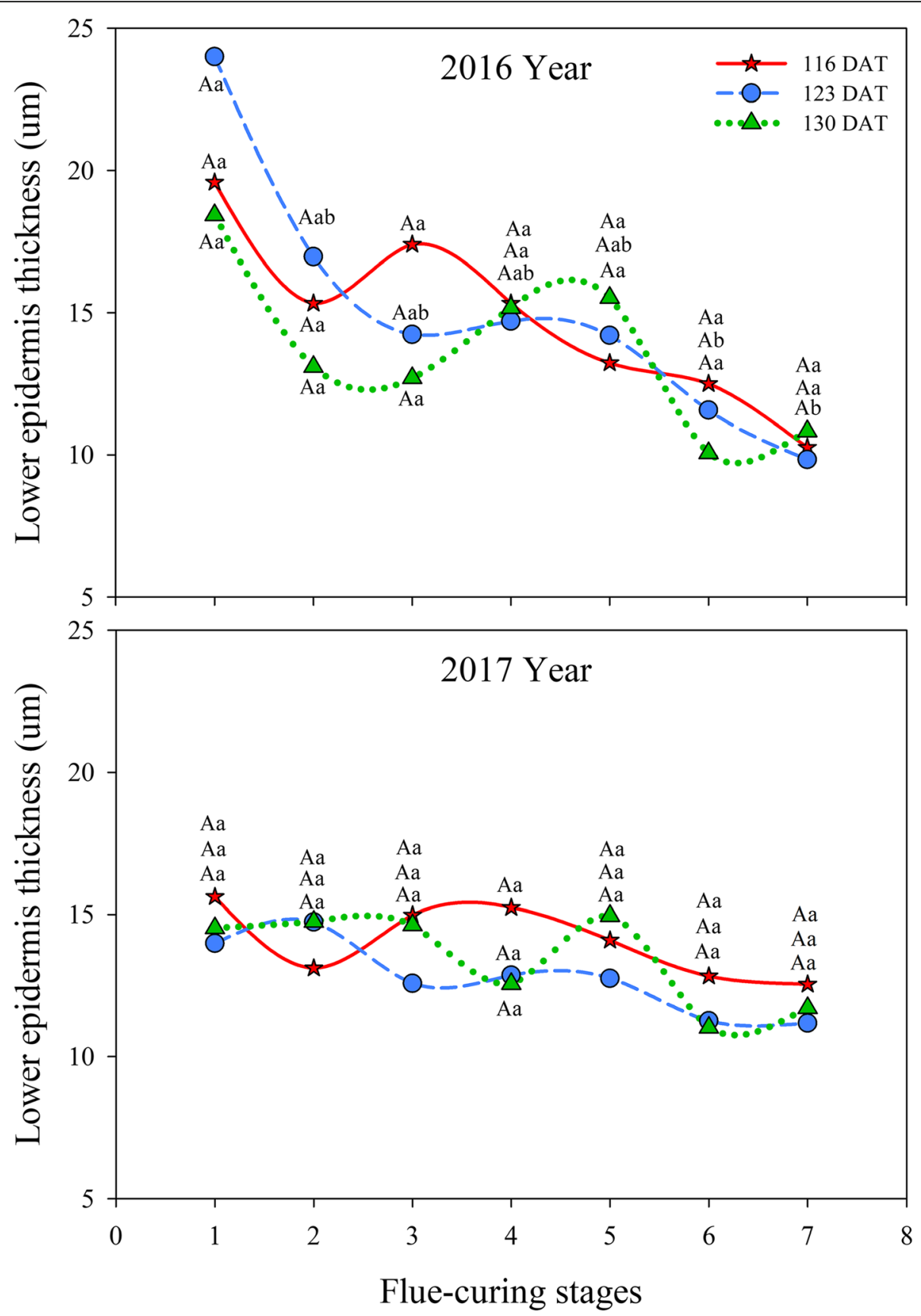

Fig. 2 Effects of interactions of different leaf ages, flue-curing stages, and years on lower epidermis thickness

\section{Effects of different leaf ages on tobacco leaf thickness during flue-curing}

Table 2 displays that leaf age and flue-curing stage significantly influence leaf thickness $(P<0.05)$.

As displayed in Fig. 5, during the two years, leaf thicknesses in the three treatments all rapidly decreased in flue-curing Stages 1 to 3, while the reduction tended to be smaller in other stages. In 2016, leaf thickness in treatments of different leaf ages showed a stable decrease during flue-curing. In 2017, the leaf thickness in treatments of different leaf ages firstly reduced and then slightly rose and decreased during flue-curing.

Effects of different leaf ages on physiological and biochemical indices of tobacco leaves during flue-curing Effects of different leaf ages on starch contents in tobacco leaves during flue-curing

Table 3 demonstrates that leaf age, flue-curing stage, and year as well as their interactions have significant effects on the starch content $(P<0.05)$. 


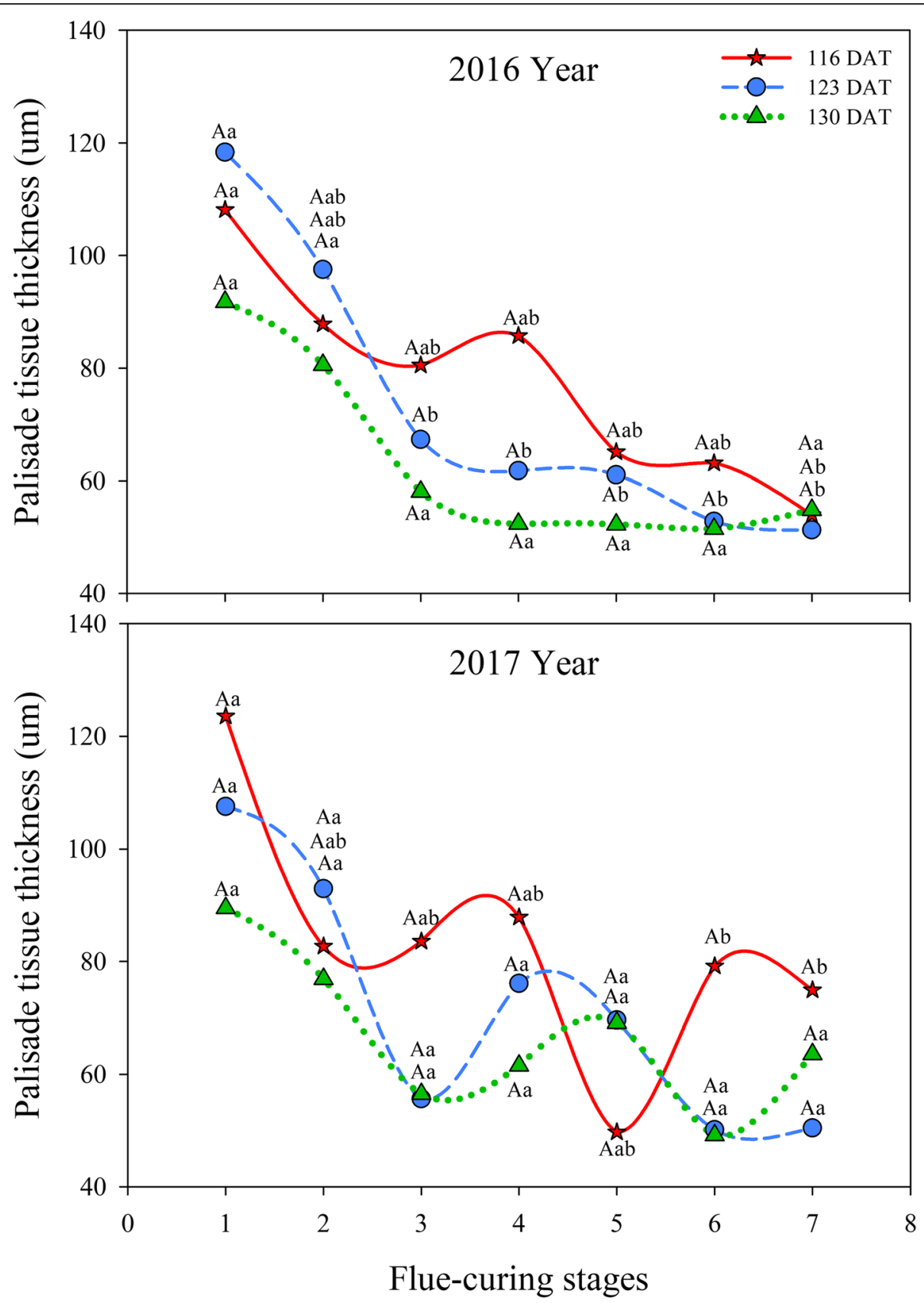

Fig. 3 Effects of interactions of different leaf ages, flue-curing stages, and years on palisade tissue thickness of tobacco leaves

As shown in Fig. 6, the 123 DAT group showed the highest starch content in flue-curing Stage 1, followed by 116 DAT and 130 DAT during the two years. In Stages 1 to 3 , starch contents rapidly decreased in different treatments and those of the three treatments in Stage 3 were significantly lower in comparison with Stage 1. Starch contents at 116 DAT and 123 DAT rapidly reduced again in Stages 4 to 5 , while those at 130 DAT rose slightly, then slowly decreased in these stages.
Effects of different leaf ages on chlorophyll contents during flue-curing

Table 3 indicates that leaf age, flue-curing stage and year as well as their interactions exert significant effects on contents of chlorophylls a and $\mathrm{b}(P<0.05)$.

It can be seen from Fig. 7 that contents of chlorophylls $\mathrm{a}$ and $\mathrm{b}$ in different treatments decreased during flue-curing. Contents of chlorophyll a in different treatments showed significant differences in fluecuring Stages 1 and 2 and the decrease in chlorophyll 


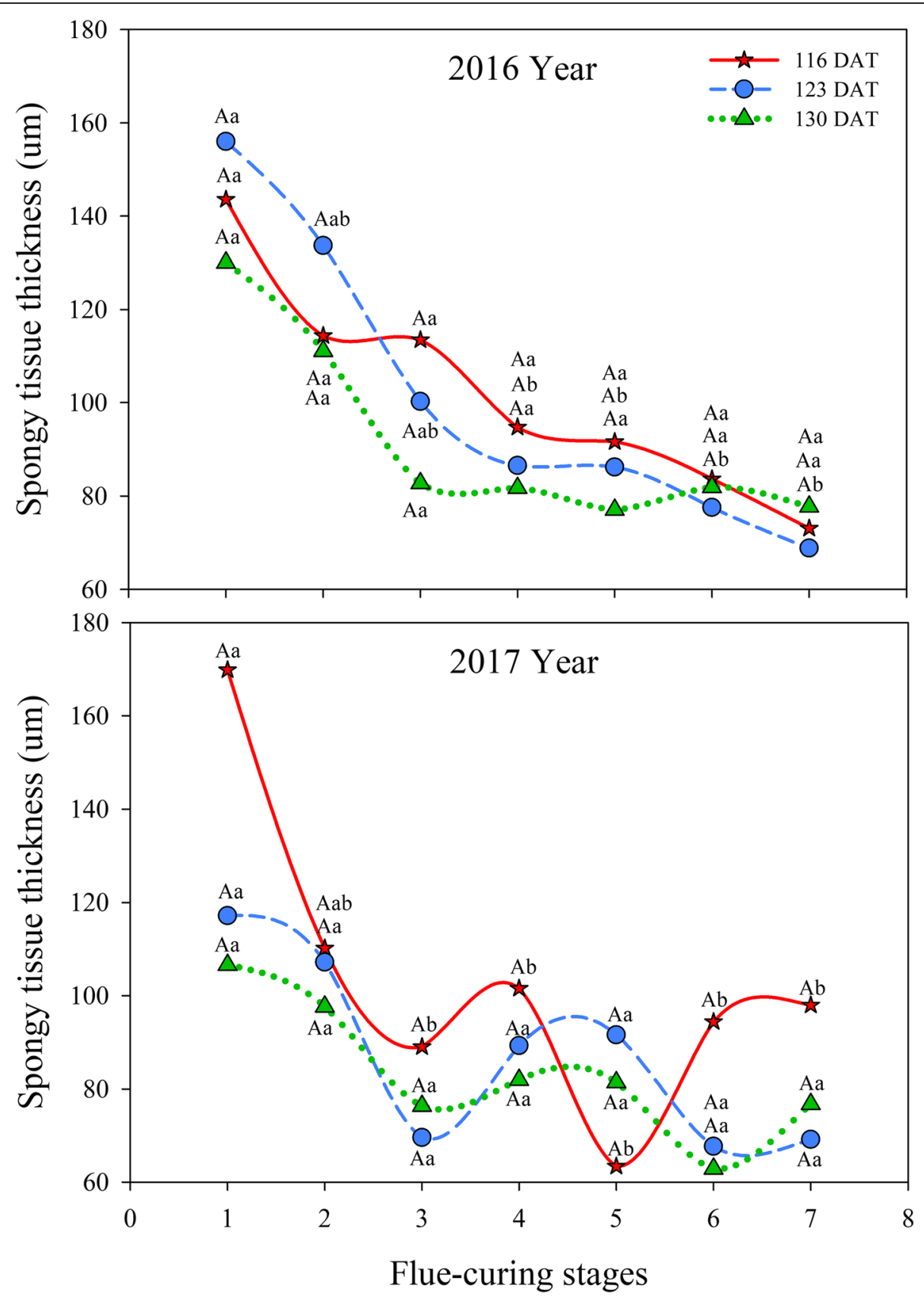

Fig. 4 Effects of interactions of different leaf ages, flue-curing stages, and years on spongy tissue thickness of tobacco leaves

a content in Stages 1 and 2 of the three treatments in 2016 was larger than that in 2017. Contents of chlorophyll a slowly decreased in other stages after Stage 2. Contents of chlorophyll b in different treatments largely reduced in Stages 1 and 2 and the decrease in 2016 was greater than that in 2017. Contents of chlorophylls a and b at 116 DAT in each stage in 2016 were higher than those in the other two treatments and the contents thereof in Stages 3 and 4 at 116 DAT were higher than those in the other treatments.

Effects of different leaf ages on carotenoid contents during flue-curing

According to Table 3, leaf age, flue-curing stage, and year as well as their interactions have significant impacts on carotenoid contents $(P<0.05)$. 


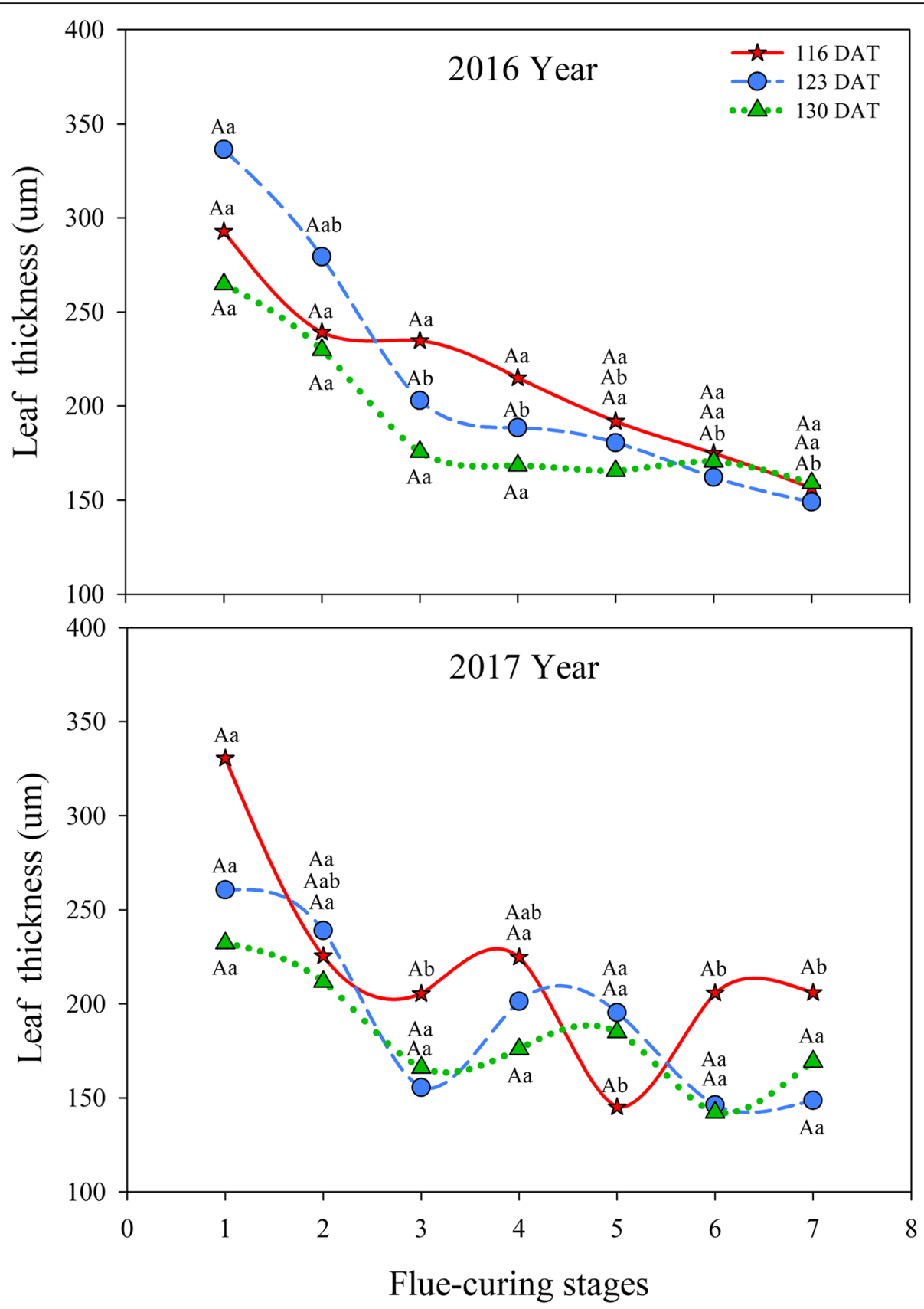

Fig. 5 Effects of interactions of different leaf ages, flue-curing stages, and years on tobacco leaf thickness

As shown in Fig. 8, carotenoid contents in different treatments decreased during flue-curing. Carotenoid contents at 116 DAT were greater than those in the other two treatments in each flue-curing stage in 2016. The three treatments were such that the carotenoid contents largely decreased in flue-curing Stages 1 to 3 in 2016 and 2017, of which the content in Stage 3 was significantly lower than those in Stage 1 and the rate of change decreased in the three treatments after Stage 3. After flue-curing, the three treatments demonstrated that carotenoid contents in Stage 7 were significantly different and the highest content was found at 116 DAT during the two years.

Effects of different leaf ages on water contents during fluecuring

In accordance with Table 3, the interaction between leaf age and flue-curing stage as well as between year and flue-curing stage significantly affect water contents $(P<0.05)$. 
Table 3 Analysis of variance for the effects of the age of tobacco leaves, year, stage and their interactions on physiological changes

\begin{tabular}{|c|c|c|c|c|c|c|c|c|}
\hline Effect/contrast & DF & Starch & Chlorophyll a & Chlorophyll b & Carotenoid & Water & Polyphenol & MDA \\
\hline & & \multicolumn{7}{|c|}{ 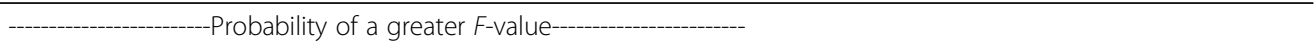 } \\
\hline Leaf age $(L)$ & 2 & $<.0001$ & $<.0001$ & $<.0001$ & $<.0001$ & $<.0001$ & $<.0001$ & $<.0001$ \\
\hline Year $(Y)$ & 1 & $<.0001$ & $<.0001$ & $<.0001$ & $<.0001$ & 0.0202 & $<.0001$ & $<.0001$ \\
\hline Stage (S) & 6 & $<.0001$ & $<.0001$ & $<.0001$ & $<.0001$ & $<.0001$ & $<.0001$ & $<.0001$ \\
\hline$L^{*} Y$ & 2 & $<.0001$ & $<.0001$ & $<.0001$ & $<.0001$ & 0.0674 & $<.0001$ & $<.0001$ \\
\hline$L * S$ & 12 & $<.0001$ & $<.0001$ & $<.0001$ & $<.0001$ & $<.0001$ & $<.0001$ & $<.0001$ \\
\hline$Y * S$ & 6 & $<.0001$ & $<.0001$ & $<.0001$ & $<.0001$ & 0.0045 & $<.0001$ & $<.0001$ \\
\hline$L^{*} Y^{*} S$ & 12 & $<.0001$ & $<.0001$ & $<.0001$ & $<.0001$ & 0.0023 & $<.0001$ & $<.0001$ \\
\hline
\end{tabular}

As shown in Fig. 9, with the advance of flue-curing, the moisture content in tobacco leaves in treatments of different ages gradually reduced. Moisture was lost slowly at first, then fast, and then slowly in tobacco leaves in different treatments during flue-curing. Less moisture in tobacco leaves was lost at a slower rate in Stages 1 to 4, while tobacco leaves lost a lot of moisture and showed a rapid rate of moisture loss in Stages 4 to 6. Moreover, the moisture loss rate of tobacco leaves slowed down in Stages 6 and 7. In different treatments, moisture contents in Stage 6 were lower than those in Stages 1 to 5. In Stages 4 to 6, moisture was lost fastest at $123 \mathrm{DAT}$, followed by $116 \mathrm{DAT}$, and $130 \mathrm{DAT}$.

\section{Effects of different leaf ages on polyphenol contents during flue-curing}

Table 3 shows that leaf age, flue-curing stage, and year as well as their interactions significantly influence polyphenol contents $(P<0.05)$.

As demonstrated in Fig. 10, polyphenol contents in different treatments gradually rose during flue-curing and the contents thereof at 123 DAT and 130 DAT were higher than that at 116 DAT on the whole. In 2016, polyphenol contents in different treatments significantly increased in Stages 1 to 2 and rose slowly rose after decreasing in Stages 3 and 4. Polyphenol contents in Stage 7 were significantly higher than those in other stages. In 2017, polyphenol contents in Stages 3 and 4 rapidly increased at 123 DAT and $130 \mathrm{DAT}$ and were significantly higher than those in Stages 1 and 2. Moreover, the content thereof at 116 DAT rapidly increased in Stages 1 to 3 and then rose gradually after a large decrease in Stages 3 and 4.

\section{Effects of different leaf ages on MDA contents during flue- curing}

Based on Table 3, leaf age, flue-curing stage, and year as well as their interactions exert significant influences on MDA content $(P<0.05)$.

It can be seen from Fig. 11 that MDA contents in different treatments gradually increased during flue-curing. MDA contents in different treatments rapidly rose in
Stages 3 to 5 and then the increase slowed down thereafter. The rising MDA content at 116 DAT was greater than those in the other two treatments in 2016, while the amplitude at 130 DAT was larger than those in the other treatments in 2017.

\section{Effects of different leaf ages on interior quality of flue- cured tobacco leaves \\ Effects of different leaf ages on total sugar and reducing sugar in flue-cured tobacco leaves}

In accordance with Table 4, leaf age and year as well as their interaction have significant effects on the contents of total sugar $(P<0.05)$, and leaf age and its interaction with year significantly affect the contents of reducing sugar $(P<0.05)$.

In 2016, the contents of total sugar and reducing sugar at 116 DAT were significantly lower than those in the other two treatments. In 2017, the contents of total sugar were the highest at $130 \mathrm{DAT}$, followed by 116 DAT, while the lowest contents were found at 123 DAT. Moreover, 123 DAT, 116 DAT, and 130 DAT were ranked from high to low according to the contents of reducing sugar. Under the same treatment, contents of total sugar and reducing sugar at 116 DAT were significantly different in different years and the contents of reducing sugar at 130 DAT showed significant differences in different years.

\section{Effects of different leaf ages on total nitrogen and nicotine in flue-cured tobacco leaves}

Table 4 shows that leaf age, year and their interaction significantly influence contents of total nitrogen and nicotine $(P<0.05)$. In 2016 , contents of total nitrogen at 116 DAT were significantly higher than those in the other two treatments, while nicotine contents at 130 DAT were significantly lower than those elsewhere. In 2017, the contents of total nitrogen were the highest at 116 DAT, followed by that at $130 \mathrm{DAT}$ and the lowest contents were found at 123 DAT: however, nicotine contents peaked at 123 DAT, followed by 130 DAT and 116 DAT. Under the same treatment, the contents of total nitrogen at 116 DAT demonstrated significant 

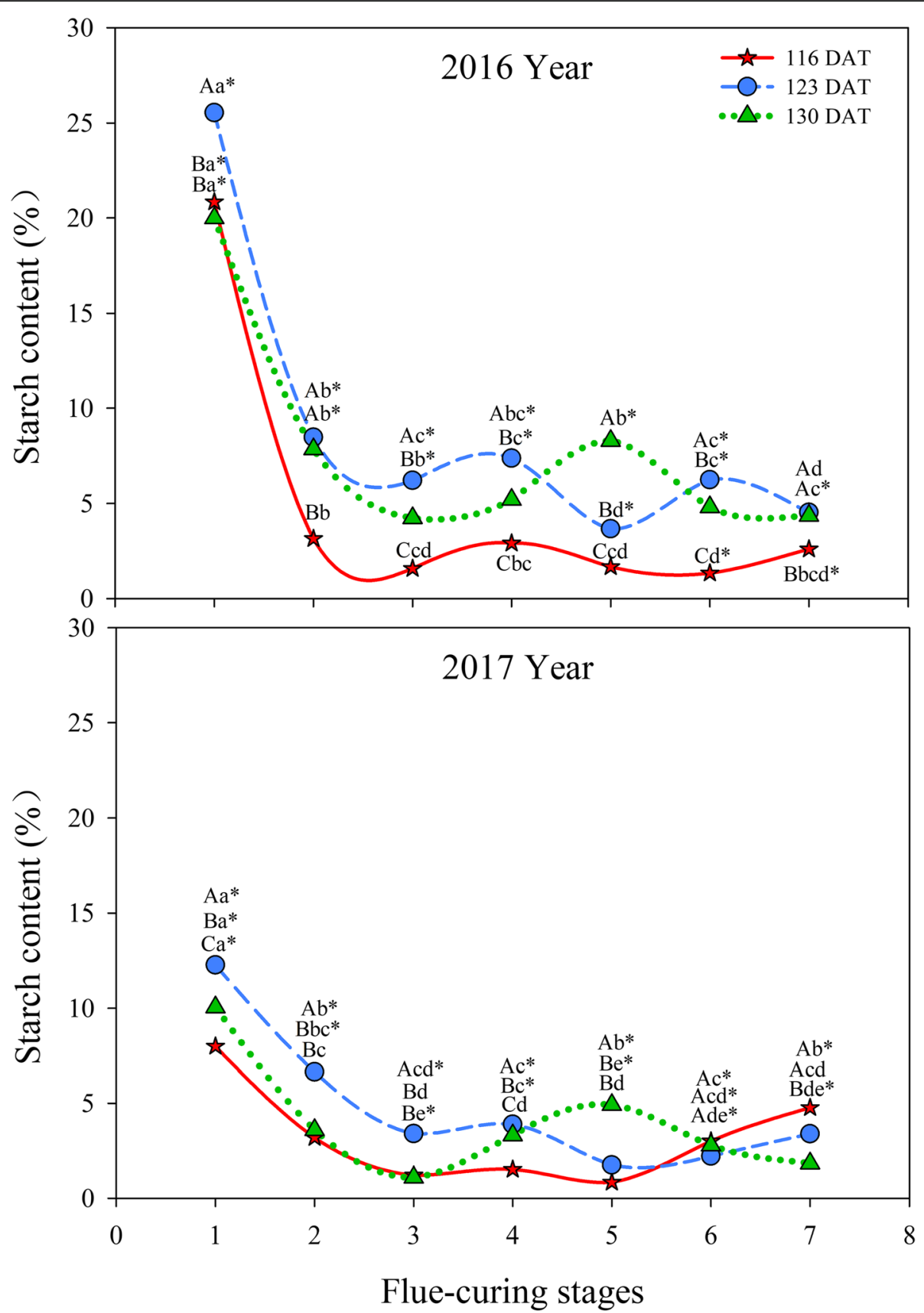

Fig. 6 Effects of interactions of different leaf ages, flue-curing stages, and years on starch contents of tobacco leaves

differences in different years and nicotine contents in the three treatments were significantly different in different years.

\section{Effects of different leaf ages on starch contents in flue-} cured tobacco leaves

Table 4 shows that leaf age, year, and their interaction significantly influence starch contents $(P<0.05)$. In 2016, starch contents at 116 DAT were significantly lower than those in the other treatments, while the contents at 123 DAT were much higher than those in the other two treatments in 2017. Under the same treatment, starch contents in different years were significantly different.

\section{Effects of different leaf ages on polyphenol contents in tobacco leaves}

Table 4 demonstrates that leaf age and year have significant influences on polyphenol contents $(P<0.05)$. In 2016, polyphenol contents at 123 DAT were significantly 


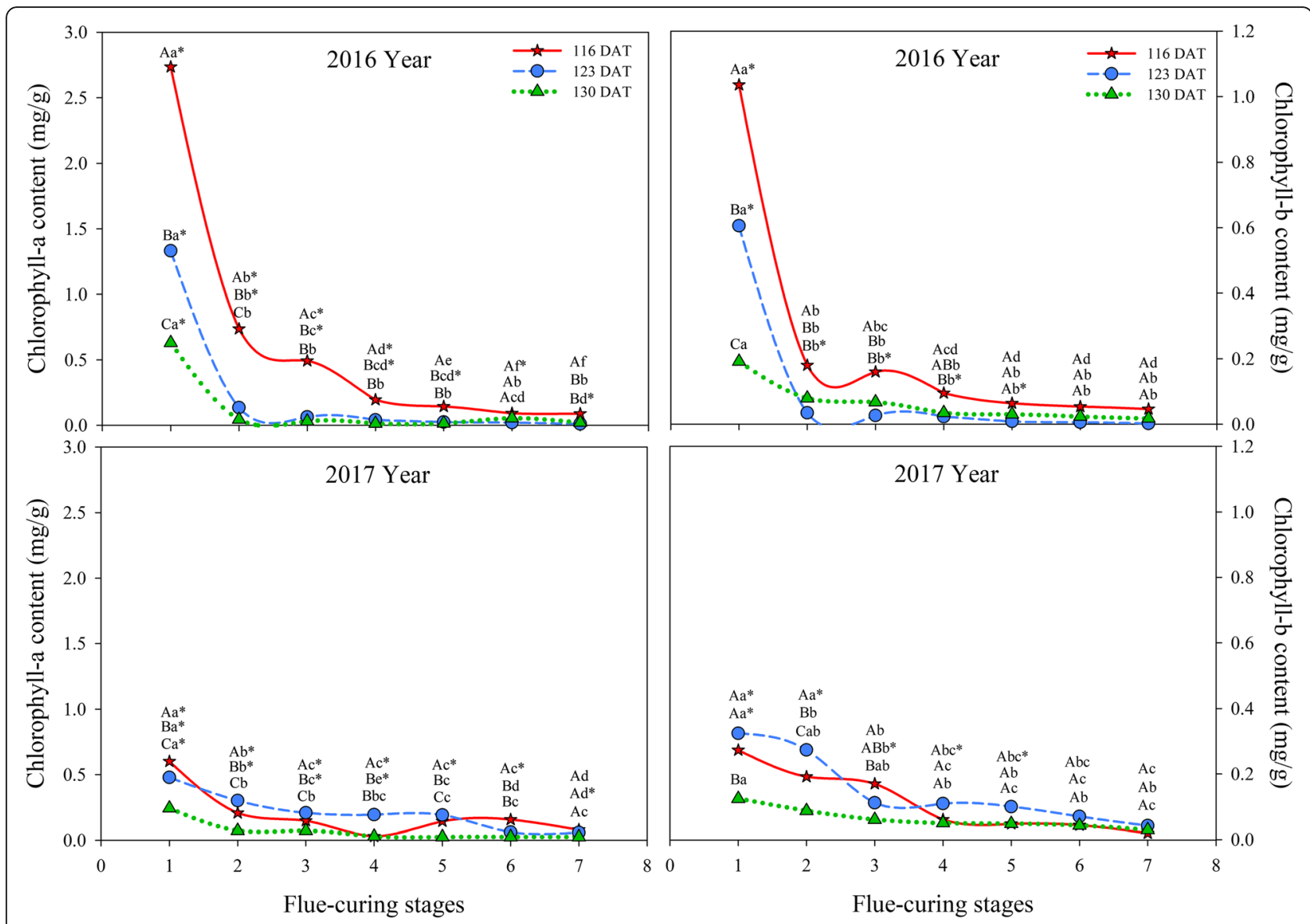

Fig. 7 Effects of interactions of different leaf ages, flue-curing stages, and years on chlorophyll contents of tobacco leaves

higher than those elsewhere, while differences in polyphenol contents in different treatments were not significant in 2017. The polyphenol contents were the highest at 116 DAT, followed by that at 123 DAT and the lowest contents were found at 130 DAT. Under the same treatment, polyphenol contents at 116 DAT and 130 DAT were significantly different in different years.

Effects of different leaf ages on sensory evaluation scores of flue-cured tobacco leaves

It can be observed from Table 4 that leaf age affects sensory evaluation scores of tobacco leaves $(P<0.05)$. Sensory evaluation scores at 130 DAT were significantly lower than those in the other two treatments in 2016 and 2017. In both years, sensory evaluation scores were the highest at 123 DAT, followed by 116 DAT, while 130 DAT had the lowest scores. Same treatment exhibited insignificant differences of sensory evaluation scores in different years. Sensory evaluation scores at 116 DAT and 123 DAT in 2017 were higher than those in 2016, while the score at 130 DAT in 2016 was higher than that in 2017.

Effects of different leaf ages on economic traits of fluecured tobacco leaves

\section{Effects of different leaf ages on yield of upper tobacco leaves}

As shown in Table 5, year has significant effects on yield of upper tobacco leaves $(P<0.05)$. In the same year, yield differences were insignificant in different treatments and the highest yield was found at 123 DAT in 2016 and 2017. Under the same treatment, yields at 123 DAT and 130 DAT were significantly different in different years and yields in the three treatments in 2016 were higher than those in 2017.

\section{Effects of different ages on average price of upper tobacco leaves}

Table 5 demonstrates that average prices in different treatments in the same year differed insignificantly and they were the highest at 123 DAT in 2016 and 


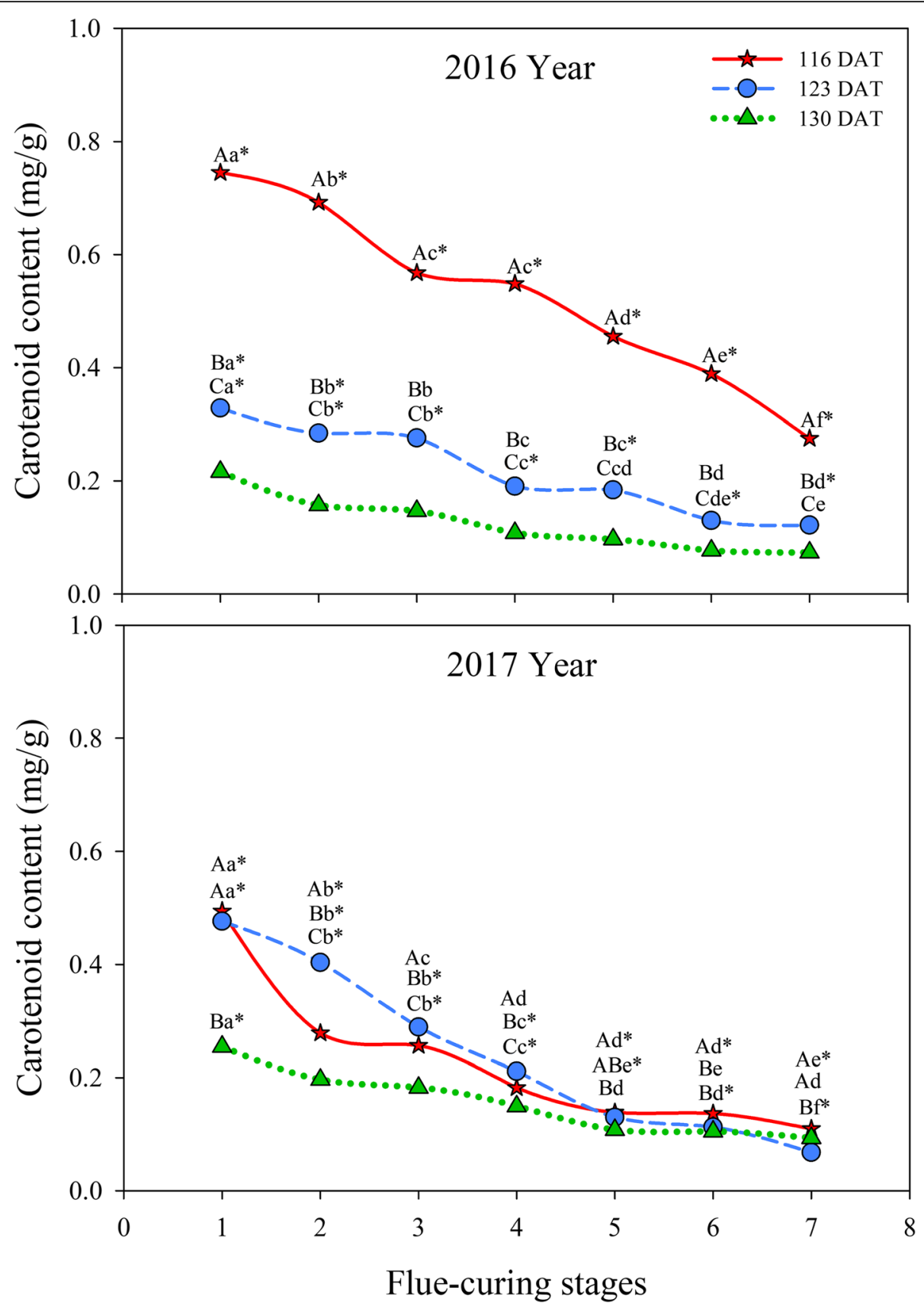

Fig. 8 Effects of interactions of different leaf ages, flue-curing stages, and years on carotenoid contents of tobacco leaves

2017. Significant differences in average prices were not found in the same treatment in different years. In 2017, average prices at 116 DAT and 123 DAT were higher than those in 2016 and 130 DAT showed the highest average prices in 2016.

\section{Effects of different leaf ages on output value of upper} tobacco leaves

As displayed in Table 5, leaf age and year, as well as their interaction did not significantly affect the output value of upper tobacco leaves. The highest output value was found at 123 DAT in 2016 and 2017. Output values at 123 DAT in 2016 were 1.86 and $6.28 \%$ higher than those at 130 DAT and 116 DAT and 8.22 and $4.17 \%$ higher than those at 130 DAT and 116 DAT in 2017. Output values in different years in the same treatment showed insignificant differences and the three treatments showed that output value in 2016 was higher than that in 2017. 

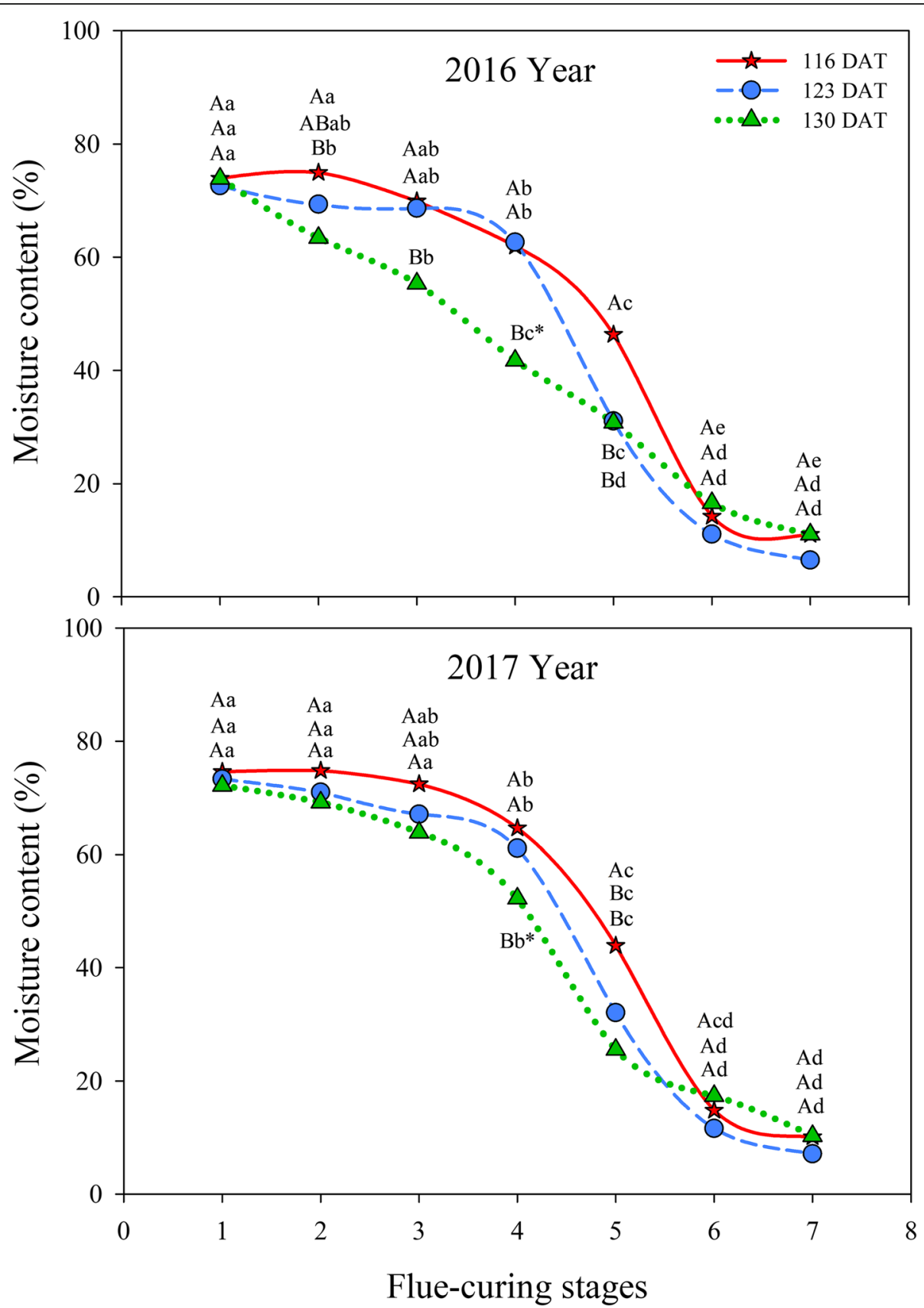

Fig. 9 Effects of interactions of different leaf ages, flue-curing stages, and years on moisture contents of tobacco leaves

Effects of different leaf ages on the proportion of superior tobacco of upper tobacco leaves

It can be seen from Table 5 that leaf age, year, and their interaction have no significant influence on the proportion of superior tobacco. In the same year, the proportions of superior tobacco showed insignificant differences in different treatments and the highest proportions of superior tobacco in 2016 and 2017 were found at $123 \mathrm{DAT}$. Under the same treatment, the differences in the proportions of superior tobacco in different years were insignificant, while the proportions in the three treatments in 2016 were higher than those in 2017.

\section{Discussion}

Morphological characteristics of tobacco leaves at different leaf age

Different leaf age tobacco leaves have different morphological characteristics. For example, the leaf length, and leaf width of old tobacco leaves exceed those of young 

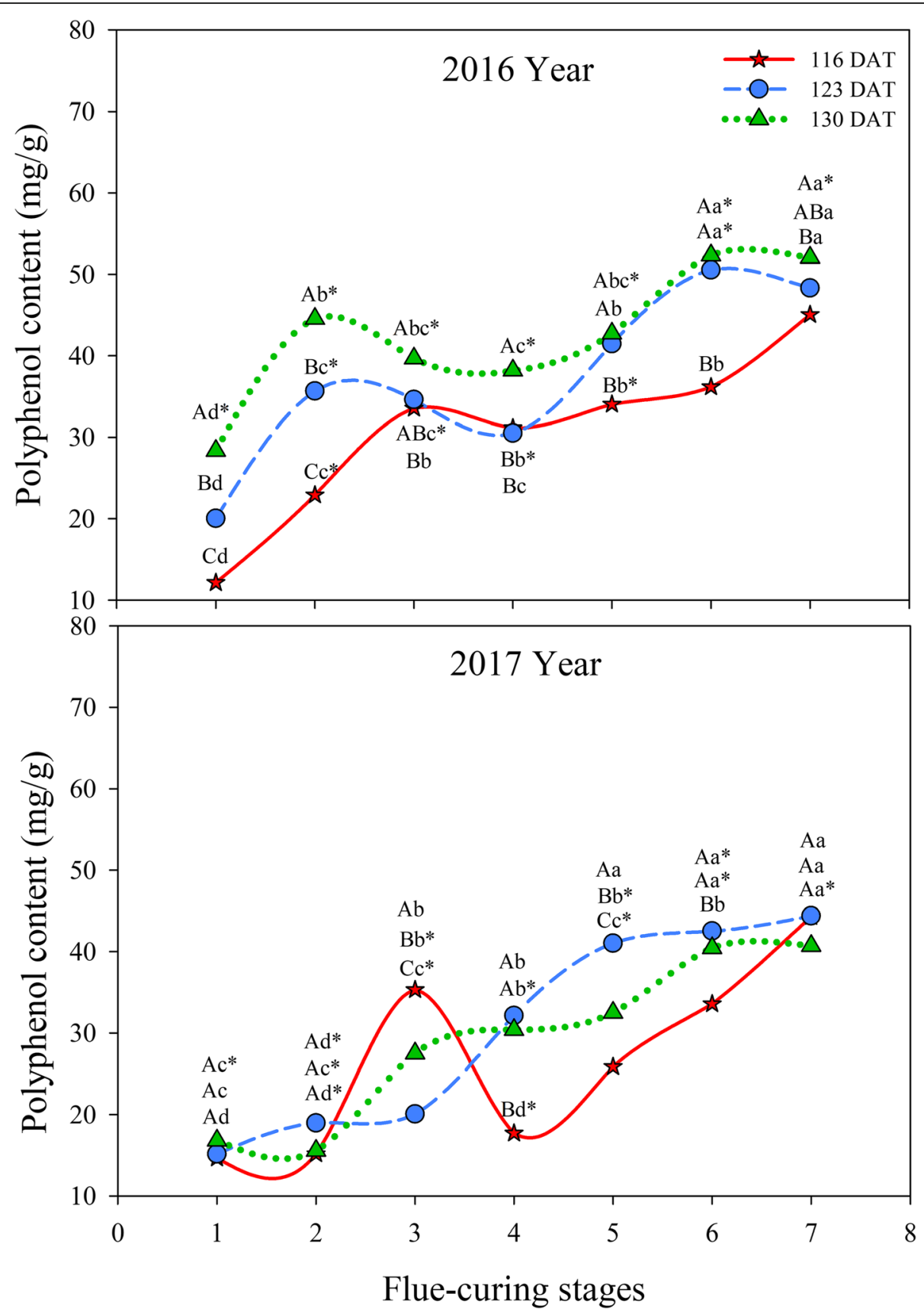

Fig. 10 Effects of interactions of different leaf ages, flue-curing stages, and years on polyphenol contents of tobacco leaves

tobacco leaves, at present, farmers, in tobacco leaf production, judge whether the tobacco leaves are mature or not mainly according to tobacco blade colour, main vein colour and villus condition. In a certain growing period, the length and width of tobacco leaves are variable and rainfall, temperature and soil condition will affect the growth of leaf length and width [17]. In this research, leaf length and leaf width did not show any significant difference between different leaf age, because tobacco leaf length and width did not increase continuously with growing time [18]. Therefore, tobacco leaf length and width can be regarded as reference indicators for tobacco maturity but not judgement indicators.

Tissue cell gap is an indirect reflection of tobacco leaf age as it increases with the senescence of tobacco [19]. The older the leaf, the bigger the tissue cell gap. In this research, for palisade tissue cell gaps, different leaf age tobacco leaves had a significant difference, 130 DAT leaf 


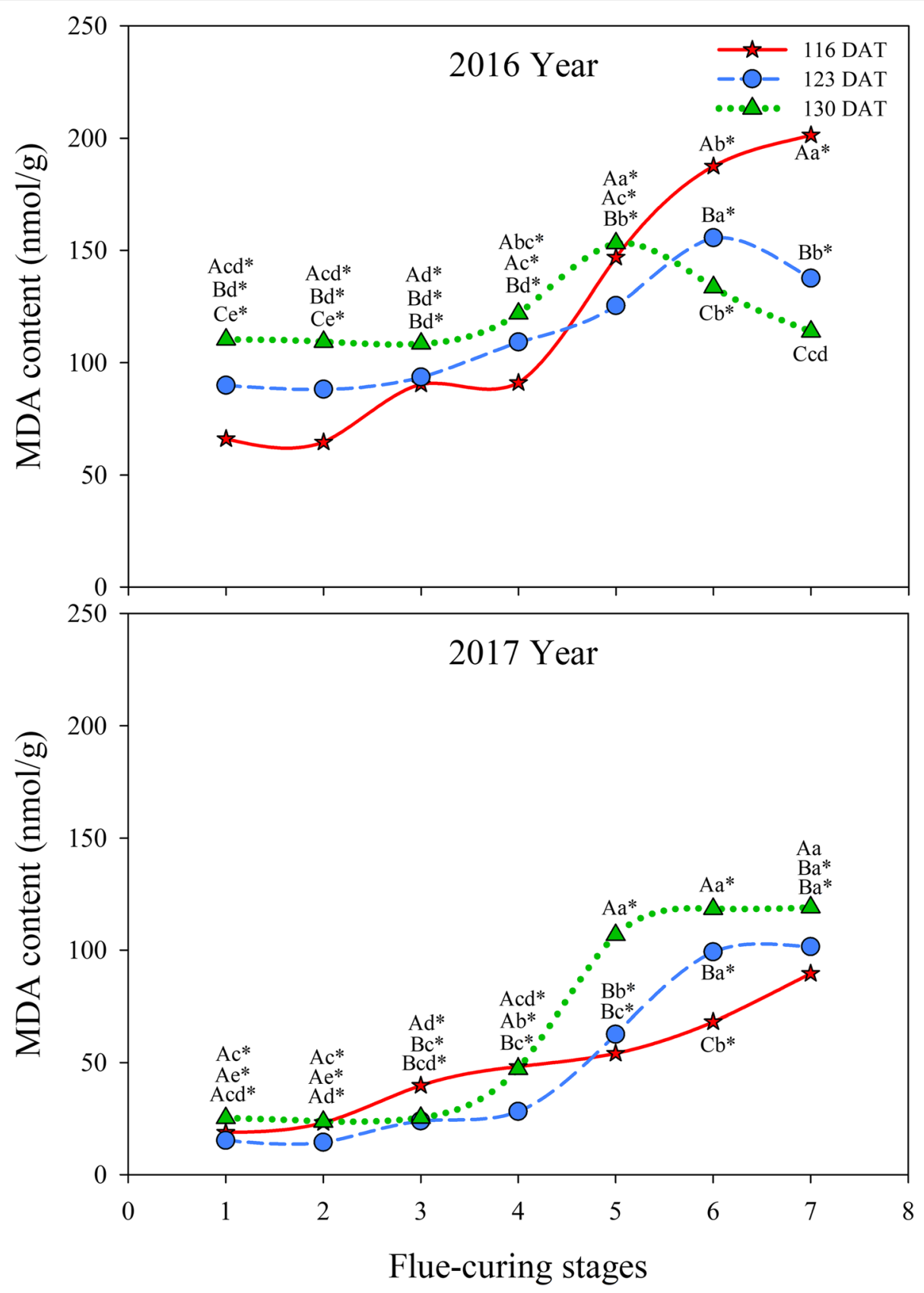

Fig. 11 Effects of interactions of different leaf ages, flue-curing stages, and years on MDA contents of tobacco leaves

age treatments have the maximum value of palisade tissue cell gap in 2016 and 2017. For sponge tissue cell gap, a leaf age of 116 DAT was significantly lower than other two leaf age treatments, and a leaf age of 123 DAT and 130 DAT did not make a significant difference because, when the tobacco leaf is younger, their cell tissue structure is tight, and the tissue cell gap is small. While when the tobacco leaf ages, the cells shrink, and the tissue cell gap decreases [20].

\section{Structural changes in tobacco leaves at different ages during flue-curing}

The structure of tobacco leaves firstly depends on leaf age for harvesting fresh tobacco leaves, because the age of fresh tobacco leaves determines maturity, while maturity sets the framework of the structure of tobacco leaves. Moreover, structure is limited by fluecuring $[20,21]$. Changes of leaf thickness and structure are mainly related to dehydration and inclusion 
Table 4 Effects of the leaf age, year, and their interactions on chemical compositions and sensory evaluation score

\begin{tabular}{|c|c|c|c|c|c|c|c|c|c|}
\hline $\begin{array}{l}\text { Leaf age } \\
\text { (A) }\end{array}$ & $\begin{array}{l}\text { Year } \\
(Y)\end{array}$ & DF & $\begin{array}{l}\text { Total sugar } \\
\text { content (\%) }\end{array}$ & $\begin{array}{l}\text { Reducing sugar } \\
\text { content (\%) }\end{array}$ & $\begin{array}{l}\text { Nitrogen } \\
\text { content (\%) }\end{array}$ & $\begin{array}{l}\text { Nicotine } \\
\text { content (\%) }\end{array}$ & $\begin{array}{l}\text { Starch } \\
\text { content (\%) }\end{array}$ & $\begin{array}{l}\text { Polyphenol } \\
\text { content (mg/g) }\end{array}$ & $\begin{array}{l}\text { Sensory } \\
\text { evaluation score }\end{array}$ \\
\hline 123 DAT & & & $27.33 \mathrm{a}$ & $24.41 \mathrm{a}$ & $2.46 \mathrm{~b}$ & $3.57 a^{*}$ & $6.3 a^{*}$ & $26.21 \mathrm{a}$ & $90.5 \mathrm{a}$ \\
\hline 130 DAT & 2016 & & 28.19 a & $26.08 a^{*}$ & $2.05 \mathrm{~b}$ & $3.09 b^{*}$ & $6.62 a^{*}$ & $19.81 b^{*}$ & $85 \mathrm{~b}$ \\
\hline 116 DAT & 2017 & & $29.56 a^{*}$ & $22.21 a^{*}$ & $2.32 a^{*}$ & $2.19 a^{*}$ & $2.65 b^{*}$ & $29.87 a^{*}$ & $90 \mathrm{a}$ \\
\hline 123 DAT & & & 26.19 a & 22.45 a & $2.18 \mathrm{a}$ & $2.38 a^{*}$ & $4.43 a^{*}$ & 31.98 a & $91 \mathrm{a}$ \\
\hline 130 DAT & & & $29.73 \mathrm{a}$ & $20.03 a^{*}$ & $2.26 \mathrm{a}$ & $2.32 a^{*}$ & $2.81 b^{*}$ & $28.94 a^{*}$ & $85 \mathrm{~b}$ \\
\hline A & & 2 & $* *$ & $* *$ & $* *$ & $* *$ & $* *$ & $* *$ & $* *$ \\
\hline Y & & 1 & $* *$ & NS & $* *$ & $* *$ & $* *$ & $* *$ & NS \\
\hline$A \times Y$ & & 2 & $* *$ & $* *$ & $* *$ & $* *$ & $* *$ & NS & NS \\
\hline
\end{tabular}

Note: Lowercase letters represent that differences are significant in different treatments in the same year $(P<0.05)$; ${ }^{*}$ indicates the significant difference in the same treatment in different years $(P<0.05) ;{ }^{* *}$ denotes the significant differences of each factor and their interactions on this index

changes. During flue-curing, dehydration of tobacco leaves and inclusion changes mainly occur in the yellowing stage and leaf-drying stage [22]. In this experiment, reduction of leaf thickness is mainly shown in Stages 2 to 5 during flue-curing, that is, the yellowing, and early leaf-dying stages. The lower epidermis thickness at 116 DAT increases before Stage 3. Some studies [23] also show that the lower epidermis thickness of immature tobacco leaves increases before rising to $38{ }^{\circ} \mathrm{C}$ during flue-curing. Based on Figs. 1 to 6 , the thinning amplitudes of palisade and spongy tissues are much greater than those of the upper and lower epidermis during flue-curing, indicating that changes in leaf thickness mainly result from palisade and spongy tissues. During flue-curing, palisade and spongy tissues in the three treatments rapidly shrink in Stages 1 to 3 because peak shrinkage of palisade and spongy tissues during flue-curing is found between 35 and $38{ }^{\circ} \mathrm{C}$, during which the acceleration of drying of tobacco leaves results in rapid shrinkage of palisade and spongy tissues [24]. During flue-curing, leaf thickness slightly increases in Stages 6 and 7, because leaf thickness slightly increases after tobacco leaves regain moisture and absorb water. Leaf thickness is a sensitive to water conditions of plants. When leaves lose water and shrink, leaf thickness reduces, while it moderately rises when leaves absorb water and expand [25].

\section{Physiological and biochemical changes of tobacco leaves at different ages during flue-curing}

Plastid pigments mainly include chlorophyll and carotenoid, which are important aroma precursors influencing appearance and quality of tobacco leaves. In flue-curing Stage 1, chlorophyll and carotenoid contents are the highest at $116 \mathrm{DAT}$, followed by 123 DAT, while the lowest contents are found at 130 DAT, because pigment contents reduce during the maturation process [26]. Degradation rates of chlorophylls at 116 DAT during flue curing are faster than those at 123 DAT and 130 DAT, which results from the too-young leaf age, so that chlorophyll degradation in tobacco leaves with a low maturity is higher than that of tobacco leaves with a high maturity [27]. It can be found (Figs. 7 and 8) that chlorophyll and carotenoid contents are significantly different in different years. The reason is that degradation and transformation of plastid pigments are greatly affected

Table 5 Effects of the leaf age, year, and their interactions on economic traits of upper leaves

\begin{tabular}{|c|c|c|c|c|c|c|}
\hline Leaf age $(A)$ & Year $(Y)$ & DF & Yield (kg/ha) & Average price (dollar/kg) & Output values (dollar/ha) & Proportions of superior tobacco (\%) \\
\hline 123 DAT & & & $860.56 a^{*}$ & $3.54 \mathrm{a}$ & 3036.63 a & $66.42 \mathrm{a}$ \\
\hline 130 DAT & 2016 & & $850.67 a^{*}$ & $3.5 \mathrm{a}$ & 2981.07 a & 65.58 a \\
\hline 116 DAT & 2017 & & $743.3 \mathrm{a}$ & $3.53 \mathrm{a}$ & 2631.96 a & $62.68 \mathrm{a}$ \\
\hline 123 DAT & & & $754.9 a^{*}$ & $3.63 \mathrm{a}$ & $2741.61 \mathrm{a}$ & $65.64 \mathrm{a}$ \\
\hline 130 DAT & & & $728.19 a^{*}$ & $3.47 \mathrm{a}$ & 2533.44 a & $62.34 \mathrm{a}$ \\
\hline A & & 2 & NS & NS & NS & NS \\
\hline Y & & 1 & $* *$ & NS & NS & NS \\
\hline$A \times Y$ & & 2 & NS & NS & NS & NS \\
\hline
\end{tabular}

Note: Lowercase letters represent significant differences for different treatments in the same year $(P<0.05)$; ${ }^{*}$ indicates significant differences for the same treatment in different years $(P<0.05) ;{ }^{* *}$ denotes the significant difference of each factor and their interaction on the index 
by climatic conditions, such as temperature, light, and rainfall [28], while the region showed different climatic conditions in 2016 and 2017. In different treatments, a lot of water is lost quickly in Stages 4 to 6 , which is the late yellowing stage and leaf-drying stage during flue-curing. During this period, a lot of chlorophylls in tobacco leaves degrade, dehydrate and dry, and decrease rate of water in this period is fast [29].

The senescence of plant tissue is always accompanied by the damage to intracellular membrane structures and the MDA content indicates the extent of damage to the membrane. In flue-curing Stages 3 to 6, MDA contents of tobacco leaves at different ages increase greatly, while water contents of tobacco leaves decrease in the same period. Some research shows that the changes in MDA contents during fluecuring are closely correlated with dehydration rate. Rapid dehydration of tobacco leaves is the direct cause of drastic membrane lipid peroxidation and increase of MDA contents [30]. In the whole fluecuring stage in 2016, the polyphenol content was the highest at $130 \mathrm{DAT}$, followed by that at 123 DAT, while that at 116 DAT showed the lowest content; however, 123 DAT, 130 DAT, and 116 DAT were ranked from high to low according to polyphenol content in 2017. This is because more mature the tobacco leaf in the field, the higher the polyphenol content; however, when the tobacco leaves are completely mature, polyphenol contents reduce and are affected by environmental factors [31]. During flue-curing, due to thermolysis of phenolic glycoside and enzymatic decomposition, phenolic substances of flue-cured tobacco change to significant extents; because of pyrolytic conversion of pyrolysates, such as lignin and cellulose in tobacco leaves, polyphenol contents in different treatments generally rise during flue-curing, while they fall slightly in Stages 3 to 5 . The reason for this that this stage is the sensitive period of browning reaction and polyphenol substances are easily oxidised to quinones [32].

During flue-curing, much of the starch is degraded in flue-curing Stages 1 to 3 and 5 and 6: the degradation of starches mainly results from combined action of amylase and amylophosphorylase. During flue-curing, starches are transferred into reducing sugar in the yellowing stage and early stem-drying stage and activities of amylase and amylophosphorylase show two peaks in middle yellowing stage and early leaf-drying stage. At the two peaks, starches are largely degraded [33, 34].

\section{Chemical quality of tobacco leaves at different ages after flue-curing}

130 DAT, 123 DAT, and 116 DAT were roughly ranked from large to small according to the content of reducing sugar of tobacco leaves after flue-curing in the two years, while $116 \mathrm{DAT}, 123 \mathrm{DAT}$, and $130 \mathrm{DAT}$ were ranked from large to small in accordance with content of total nitrogen. In comparison with 116 DAT and 123 DAT, 130 DAT has an older leaf age, so its maturity is higher. With increasing maturity, the content of reducing sugar increases, while content of total nitrogen decreases [35]. With the increase of maturity, tobacco leaves gradually change from $\mathrm{C}$-metabolism and accumulation to $\mathrm{N}$ metabolism, so sugar contents in flue-cured tobacco leaves reduce, while total nitrogen and nicotine rise [36].

Starch metabolism, as the primary metabolism in tobacco leaves, affects the internal quality of tobacco leaves. Starch contents in flue-cured tobacco leaves in different treatments rise with increasing leaf age, because starch contents in tobacco leaves gradually increase with greater maturity. The maturation stage of flue-cured tobacco is a period of rapid synthesis and accumulation of starches in tobacco leaves, and accumulation of starches in tobacco leaves with long leaf age is larger than that at short leaf age. Starch in tobacco leaves peaks at physiological maturity stage and then begins to decrease [37, 38].

Polyphenol, as an important index of measuring quality of tobacco, influences colour and lustre as well as aroma and taste of tobacco leaves. Phenylalanine ammonialyase is the key enzyme used to catalyse the synthesis of polyphenols, while polyphenol oxidase is the key enzyme used to catalyse the degradation of polyphenols. The activities of such two enzymes during flue-curing determine polyphenol contents [39]. Polyphenol contents in tobacco leaves rise with maturity and polyphenol accumulation begins to decrease when reaching physiological maturity [40]. Polyphenol content in flue-cured tobacco leaves at 123 DAT is higher than those at 116 DAT and 130 DAT, indicating that $123 \mathrm{DAT}$ is moderately mature and a lot of polyphenols are accumulated in fresh tobacco leaves. Moreover, phenylalanine ammonialyase of tobacco leaves with a moderate maturity during flue-curing has a high activity and is not easily oxidised into quinone by polyphenol oxidase [41].

\section{Economic traits of upper tobacco leaves at different ages after flue-curing}

Mature tobacco leaves at a proper age have higher quality and economic value. If the leaf is too young, then such short leaves are not matured adequately and their weights are insufficient after picking, which reduces yield and causes economic loss. If a leaf is too long, vegetables such as lettuce, escarole, spinach, Swiss chard are difficult to store and process [13]. In the experiment, the proportion of superior tobacco, average price, yield and output value of upper tobacco 
leaves in 123 DAT are superior to those in the other two treatments. In comparison with specimens at 123 DAT, 116 DAT shows a shorter leaf age and lower maturity while 130 DAT demonstrates longer leaf age and over-mature tobacco leaves. In the three treatments, the yield of upper leaves at 116 DAT is lowest, because the dry weight of crops is highly correlated with leaf area and the increase of leaf area can increase the dry weight of crops to some extent [42]. Leaf age is an important factor in controlling leaf area index to improve yield [43]. At 116 DAT, the tobacco leaves are young and smaller in length and width, so that less dry matter is accumulated on a small area of leaf.

Previous studies found that tobacco leaves with a high maturity have increasing average price and yield, are golden yellow and contain sufficient oil after flue-curing [44]. In the research, yield, output value, and average price of upper tobacco leaves at 123 DAT were superior to those in the other two treatments, demonstrating that tobacco leaves at 123 DAT were harvested at an appropriate maturity.

\section{Conclusion}

Age of tobacco leaves lays the foundation of leaf structure and chemical compositions and harvesting at an optimal leaf age is an important precondition to ensure quality of tobacco leaves during flue-curing. This study compared physiological and biochemical metabolism of tobacco leaves in treatments of different leaf ages during flue-curing and found that tissue cell gap increased with the increase of leaf age, the thicknesses of upper and lower epidermis as well as palisade and spongy tissues show a W-shaped trend during flue-curing. The older the leaf, the faster the thickness of its structure decreases. With the advance of flue-curing, starch, chlorophyll, carotenoid, and water contents in tobacco leaves at different ages decrease, while polyphenol and MDA contents increase. Furthermore, the older the leaf, the faster the chlorophyll, carotenoid, and water contents reduce during flue-curing, while the faster the polyphenol and MDA contents increase. With the increase of leaf age, contents of total sugar, reducing sugar, and starch in flue-cured tobacco leaves rise, while contents of total nitrogen and nicotine reduce. Flue-cured tobacco leaves at 123 DAT show good economic traits and the highest sensory evaluation score.

The research demonstrates that upper tobacco leaves at 123 DAT were harvested at a leaf age with an appropriate maturity and have an optimal chemical composition after flue-curing. Moreover, their economic value is maximised and the availability of tobacco leaves is improved. For upper tobacco leaves that are too young, pigments and starches degrade slowly during flue-curing and contents of total nitrogen and nicotine are high in such flue-cured tobacco leaves. While flue-curing tobacco leaves at too great an age, water is fast lost and pigments are quickly degraded, so polyphenol and MDA contents in fluecured tobacco leaves increase. To sum up, 123 DAT can be selected as the quantitative standard for properly harvesting mature tobacco leaves in production.

\section{Methods}

\section{Experimental location and materials}

This study was conducted at Yiliang, Kunming, Yunnan, China $\left(24^{\circ} 91^{\prime} \mathrm{N} 103^{\circ} 14^{\prime} \mathrm{W}\right)$. The soil was a sandy red soil (silty loam), which is the dominant soil type for flue-tobacco production in Yunnan. This research site has an altitude of $1539 \mathrm{~m}$, with annual average temperature of $16.3^{\circ} \mathrm{C}$, an annual average total precipitation of $912 \mathrm{~mm}$ and $2177 \mathrm{~h}$ of annual average sunshine. Details of soil nutrient levels in the research site are provided in Table 6 and a summary of the mean monthly temperatures and total monthly precipitation is provided in Table 7.

\section{Requirement for field management}

Tobacco varieties K326 were provided by Zhongyan Tobacco Seed Co., Ltd., China. For the tobacco plants assessed in the experiment, young seedlings growing under film were transplanted to the field on 15 April 2016 and 18 April 2017, respectively. Pure nitrogen at $90 \mathrm{~kg} / \mathrm{ha}$ was applied during transplanting and fertiliser at $\mathrm{N}: \mathrm{P}_{2} \mathrm{O}_{5}: \mathrm{K}_{2} \mathrm{O}(1: 1: 2.5)$ was applied. More fertiliser from the bottom of the ponds was applied and $50 \%$ of the total amount thereof was used as base fertiliser, while $25 \%$ was used as seedling promoting fertiliser, and the other $15 \%$ was additional fertiliser. All fertiliser was applied $25 \mathrm{~d}$ after transplantation. When the tobacco plants grew to 23 to 25 leaves, they were topped: at time of topping (removal of flowers from

Table 6 Contents of soil nutrients in Yiliang tobacco-growing area

\begin{tabular}{|c|c|c|c|c|c|c|c|c|}
\hline $\begin{array}{l}\text { Soil } \\
\text { Type }\end{array}$ & $\mathrm{pH}$ & $\begin{array}{l}\text { Organic } \\
\text { matter }\left(\mathrm{g} \cdot \mathrm{kg}^{-1}\right)\end{array}$ & $\begin{array}{l}\text { Total nitrogen } \\
\left(\mathrm{g} \cdot \mathrm{kg}^{-1}\right)\end{array}$ & 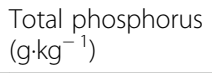 & $\begin{array}{l}\text { Total potassium } \\
\left(\mathrm{g} \cdot \mathrm{kg}^{-1}\right)\end{array}$ & $\begin{array}{l}\text { Soil available } \\
\text { nitrogen }\left(\mathrm{mg}^{\mathrm{kg}}{ }^{-1}\right)\end{array}$ & $\begin{array}{l}\text { Soil available } \\
\text { phosphorus }\left(\mathrm{mg} \cdot \mathrm{kg}^{-1}\right)\end{array}$ & $\begin{array}{l}\text { Soil available } \\
\text { potassium }\left(\mathrm{mg} \cdot \mathrm{kg}^{-1}\right)\end{array}$ \\
\hline $\begin{array}{l}\text { Red } \\
\text { soil }\end{array}$ & 6.42 & 23.96 & 0.24 & 0.18 & 1.92 & 119.37 & 29.53 & 168.74 \\
\hline
\end{tabular}


Table 7 The average monthly air temperature and total monthly precipitation (2016 to 2017)

\begin{tabular}{|c|c|c|c|c|c|c|c|}
\hline \multirow[t]{2}{*}{ Year } & \multicolumn{7}{|c|}{ Precipitation } \\
\hline & April & May & June & July & August & September & Growing season \\
\hline \multicolumn{8}{|c|}{ 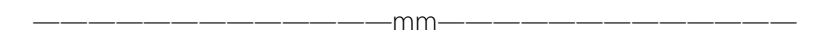 } \\
\hline 2016 & 14.4 & 58.5 & 57.6 & 47.7 & 136.6 & 115.2 & 430 \\
\hline \multirow[t]{2}{*}{2017} & 40.5 & 21.8 & 178.4 & 318.4 & 145.5 & 125.4 & 830 \\
\hline & & & & 10 & merature & -1, & \\
\hline 2016 & 20.2 & 22.2 & 22.7 & 22.7 & 22.5 & 20.0 & 130.3 \\
\hline 2107 & 18.3 & 21.2 & 23.1 & 21.3 & 22.5 & 21.8 & 128.2 \\
\hline
\end{tabular}

the top of the plant), two or three useless basal leaves were removed and 20 effective leaves per plant were reserved. After topping on 20 July in 2016 and 2017, chemical suckercides "Maleic hydrazide" (the active ingredient: $\quad \mathrm{N}$-sec-Butyl-4-(2-methyl-2-propanyl)-2,6dinitroanilin) was applied to suppress buds, so that there were no tobacco flowers on the top and branches on the middle part. Other cultivation measures were applied according to the technical requirements of high-quality tobacco production in Kunming city, Yunnan Province, China.

\section{Experimental design}

The experiment was designed with three different treatments (Table 8), 116 DAT, 123 DAT, and 130 DAT. Different treatments at each time of harvest included approximately 1000 pieces tobacco leaves. The samples of tobacco leaves at different ages were fluecured with the same flue-curing process. The samples were piecewise collected in seven stages (Fig. 12), i.e. Stage 1 (before flue-curing), Stage 2 (dry-bulb temperature of $35^{\circ} \mathrm{C}$ ), Stage 3 (dry-bulb temperature of $38^{\circ} \mathrm{C}$ ), Stage 4 (dry-bulb temperature of $42^{\circ} \mathrm{C}$ ), Stage 5 (dry-bulb temperature of $48^{\circ} \mathrm{C}$ ), Stage 6 (dry-

Table 8 Experiment design and experiment code

\begin{tabular}{|c|c|c|c|}
\hline Year & Transplanting date & $\begin{array}{l}\text { Harvested date } \\
\text { for upper leaves }\end{array}$ & Treatment code \\
\hline \multirow[t]{3}{*}{2016} & 15 April & 9 August & $\begin{array}{l}116 \text { DAT } \\
\text { (Days after transplanting) }\end{array}$ \\
\hline & & 16 August & $\begin{array}{l}123 \text { DAT } \\
\text { (Days after transplanting) }\end{array}$ \\
\hline & & 23 August & $\begin{array}{l}130 \text { DAT } \\
\text { (Days after transplanting) }\end{array}$ \\
\hline \multirow[t]{3}{*}{2017} & 18 April & 12 August & $\begin{array}{l}116 \text { DAT } \\
\text { (Days after transplanting) }\end{array}$ \\
\hline & & 19 August & $\begin{array}{l}123 \text { DAT } \\
\text { (Days after transplanting) }\end{array}$ \\
\hline & & 26 August & $\begin{array}{l}130 \text { DAT } \\
\text { (Days after transplanting) }\end{array}$ \\
\hline
\end{tabular}

bulb temperature of $54{ }^{\circ} \mathrm{C}$ ), and Stage 7 (after fluecuring).

\section{Determination items and methods Structure analysis}

Different treatments used nine fresh tobacco leaves and we measured leaf length and leaf width, and the sample leaves were fixed with FAA (50\% alcohol) fixative, and specimens were quickly embedded in paraffin and sliced, observed under Motic optical microscope, and statistically analysed for palisade tissue cell gap. The tobacco samples obtained in the seven flue-curing stages were sampled at a position $10 \mathrm{~mm}$ from the chief vein in the middle of a leaf by using a hole punch with the diameter of $10 \mathrm{~mm}$ and the sampled leaves were placed into formalin-acetoalcohol (FAA) stationary liquid. A section was made by using paraffin. The section with thickness of $10 \mu \mathrm{m}$ was dyed with hematoxylin and then thicknesses of upper and lower epidermis as well as palisade and spongy tissues were measured by using a Motic optical microscope. Based on this, structural differences in tobacco leaves at different ages during flue-curing were compared.

\section{Analysis of physiological indices}

Contents of chlorophyll, carotenoid, water, starch, polyphenol, and MDA of the tobacco samples in the seven flue-curing stages were determined. Chlorophyll and carotenoid were determined by using spectrophotometry, while starch was determined by utilising a continuous flow method [45]. Moreover, highperformance liquid chromatography was used to determine polyphenol and MDA contents. All chemical composition determination methods are determined according to the Chinese tobacco industry standard method, and the measurement results are recognised by the tobacco industry.

\section{Economic traits}

We had the tobacco samples rated in accordance with National Standard (GB2635-92) and recorded the grading results. According to national purchasing data and supervision and inspection data of grade quality during industry-commerce handover in that year, the average price and proportion of superior tobacco could be estimated. Moreover, based on weight of the tobacco samples, yield, and output value of tobacco leaves were calculated.

\section{Analysis of chemical compositions}

Contents of total sugar, reducing sugar, starch, and protein were determined by using the Pulse-3000 continuous flow analyser, and total nitrogen was determined by 


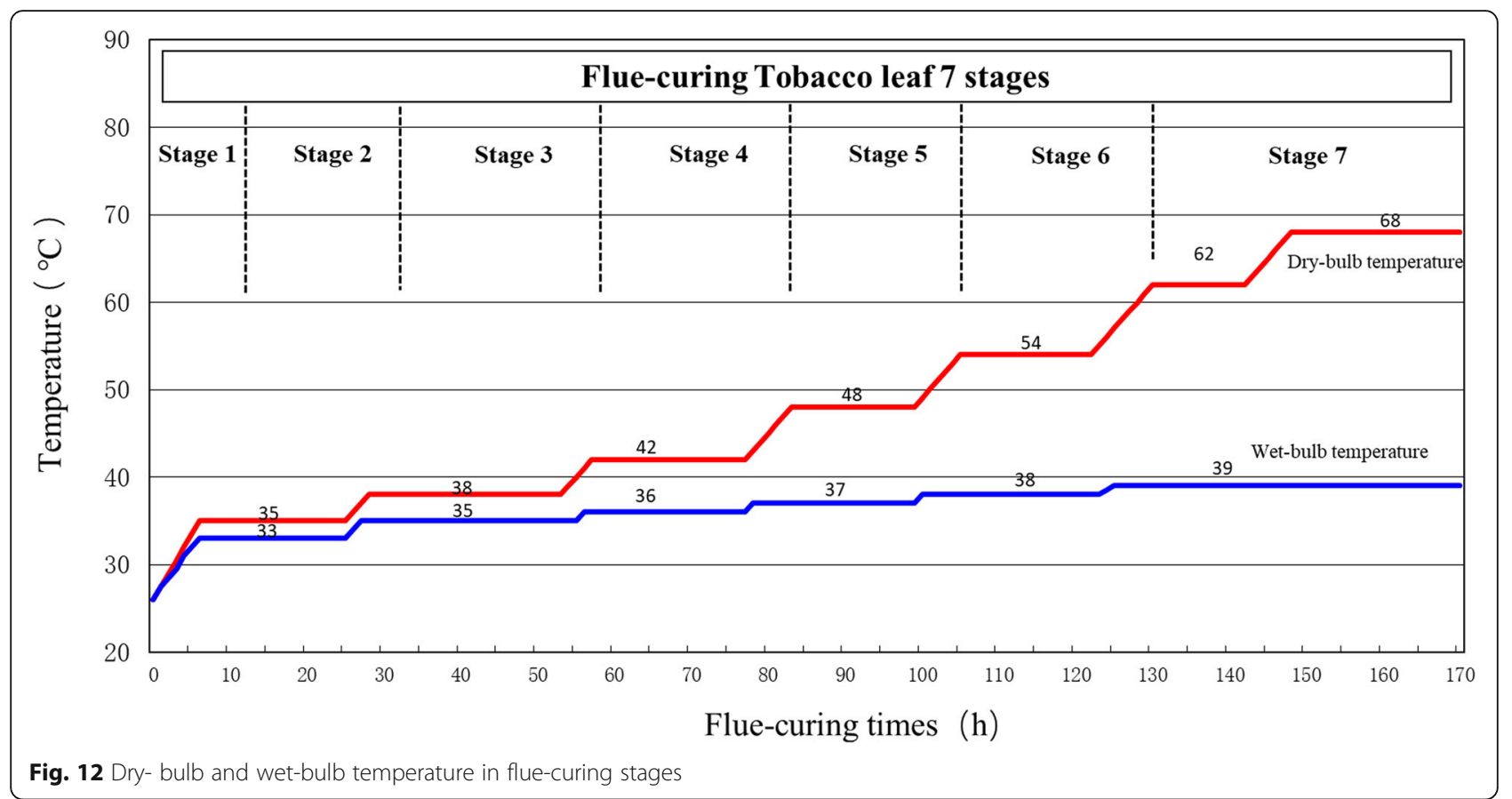

utilising the perchloric-sulphuric acid digestion method. Furthermore, an ultraviolet (UV) spectrophotometric method was applied to determine nicotine contents.

\section{Statistical analysis}

Data analysis was conducted using the General Linear Model (GLM) procedure available in the SAS $9.3 \mathrm{com}-$ puter package (SAS Institute Inc., Cary, NC). The results indicate that there were significant treatment effects if the probability $P$ was smaller than 0.05 for a greater $F$ statistic. Tukey's honest significant difference (HSD) test was carried out for separation of the means at the 95\% confidence level. Sigma Plot 12.3 (Systat Software Inc., Chicago, IL, USA) was used to produce all associated output plots.

\section{Abbreviations}

DAT: Days after transplanting; MDA: Malondialdehyde

\section{Acknowledgements}

The authors are thankful to Dr. Junying Li for his valuable assistance and advice in the preparation of this paper.

\section{Authors' contributions}

Conceptualization, ZZ, YZ and CZ; Formal Analysis, KR, JG, XH and YC; Investigation, $\mathrm{XH}, \mathrm{YJ}$ and JS; Writing - Original Draft Preparation, $Y C$; Writing - Review \& Editing, YC, CZ. All authors have read and approved the manuscript.

\section{Funding}

This work was financially supported in part by the National Natural Science Foundation of China Grant (41601330), and the Yunnan Applied Basic Research Project (2017FB074), and the Yunnan Provincial Tobacco Monopoly Bureau Grants (2016YN28, 2017YN09, 2018530000241017, and 2019530000241019). Authors thank to Yunnan Technology Innovation Program (2019HB068) and Yunnan Ten Thousand People Program (2018-73) for supporting Congming Zou. The funders did not play any role in the design, collection, analysis, interpretation of the relevant data, or in writing the manuscript.

Availability of data and materials

All data generated or analysed during this study are included in this published article [and its supplementary information files].

Ethics approval and consent to participate

Not applicable.

\section{Consent for publication}

Not applicable.

\section{Competing interests}

The authors declare that they have no competing interests. All authors approved the final manuscript.

\section{Author details}

${ }^{1}$ Yunnan Academy of Tobacco Agricultural Sciences, 33 Yuantong Street, Kunming, Yunnan 650021, People's Republic of China. ${ }^{2}$ College of Tobacco Science, Yunnan Agricultural University, Kunming 650201, Yunnan, China.

${ }^{3}$ Faculty of Life Science and Technology, Kunming University of Science and Technology, 727 South Jingming Road, Kunming 650500, Yunnan, China.

Received: 18 October 2019 Accepted: 18 November 2019

Published online: 16 December 2019

\section{References}

1. Zhao MQ, Yu JC, Cheng YY, Wang YS. On relations between maturity and aroma quality in flue-cured tobacco leaves. J China Agric Univ. 2005;10(3): $10-4$.

2. Cai XJ, Wang XM, Yin QS. Preliminary study on quantitative analysis of fluecured tobacco appearance quality indices. Tob Sci Technol. 2004;42(6):37-9.

3. Groom PK, Lamont BB, Markey AS. Influence of leaf type and plant age on leaf structure and sclerophylly in Hakea (Proteaceae). Aust J Bot. 1997;45(5): 827-38.

4. Guo WM, Yin QS, Zhang YL, He B, Wang XM, Wang GS. Surface microscopic morphology characteristics of flue-cured tobacco from different stalk positions and their relationships with selected apparent and physical quality indexes. Acta Tab Sin. 2017;23(1):62-8. 
5. Kisaki T, Hirabayashi S, Yano N. Effect of the age of tobacco leaves on photosynthesis and photorespiration. Plant Cell Physiol. 1973;14(3):505-14.

6. Kitajima K, Mulkey SS, Samaniego M, Joseph WS. Decline of photosynthetic capacity with leaf age and position in two tropical pioneer tree species. Am J Bot. 2002;89(12):1925-32.

7. Parish RW. Studies on senescing tobacco leaf disks with special reference to peroxidase: II. The effects and interactions of Proline, Hydroxyproline and kinetin. Planta. 1968:82:14-21.

8. Reifenrath K, Müller C. Species-specific and leaf-age dependent effects of ultraviolet radiation on two Brassicaceae. Phytochemistry. 2007;68(6):875-85.

9. Hikosaka K. Effects of leaf age, nitrogen nutrition and photon flux density on the organization of the photosynthetic apparatus in leaves of a vine (ipomoea tricolor cav.) grown horizontally to avoid mutual shading of leaves. Planta. 1994;97(4):451-7.

10. Williams RS, Lincoln DE, Norby RJ. Leaf age effects of elevated $\mathrm{CO}_{2}$-grown white oak leaves on spring-feeding lepidopterans. Glob Chang Biol. 2010; 4(3):235-46.

11. Li BH, Zhang Q, Shi BS, Liu DY, Liang HY, Gao YH, Li D. The variation of the leaf area, color and main organic contents in different leaf age of Chinese buckeyes. J Agric Univ Hebei. 2007;5:32-5.

12. Brown GW, Terrill TR. Effects of method of harvest on flue-cured tobacco part II. Chemical components 1. Agron J. 1973;65(2):268-73.

13. Gil MI, Tudela JA, Martínez-Sánchez A, Luna MC. Harvest maturity indicators of leafy vegetables. Stewart Postharvest Rev. 2012;8(1):1-9.

14. Bowman DT. Assessing holding ability in flue-cured tobacco cultivars. Tob Sci. 2004:46:28-30

15. Zhang $Y Q$, Li QS, Wang $C Y$, Tan $X L$, Xu JL, Yang JT, Sun $Y$, Chen $C Y, X u X H$. Study on color parameters and curing characteristics of flue-cured tobacco leaves in process of maturity. Southwest China J Agric Sci. 2018;31(1):62-7.

16. Chaplin JF. Flue-cured tobaccos with varied ripening pattern for modified harvest systems 1. Agron J. 1975;67(3):354-8.

17. Cakir R, Cebi U. The effect of irrigation scheduling and water stress on the maturity and chemical composition of Virginia tobacco leaf. Field Crop Res. 2010;119(2-3):269-76.

18. Avery GS. Structure and development of the tobacco leaf. Am J Bot. 1933; 20(9):565-92.

19. Xu XY, Liao KF, Dai JR, Hu WZ, Cheng SY, Duan YM, Wang F. A study on different harvest maturity levels in leaf structures and physiological and biochemical properties of fresh tobacco leaves. J Yunnan Univ. 2017;39(2): 313-23.

20. Zhang ST, Yang XB, Wang YH, Li RC, Ma YQ. Comparison of tissue of fresh flue-cured tobacco leaves with different maturity. Tob Sci Technol. 2005;1: 38-40.

21. Gong CR, Yang HW, Wang NR. Tobacco curing. Beijing: China Agriculture Press; 2011. p. 95-8.

22. Zou CM, Hu XD, Huang W, Zhao GK, Yang XB, Jin Y, Gu HG, Yan F, Li Y, Wu $\mathrm{Q}$, Xiong KS. Different yellowing degrees and the industrial utilization of flue-cured tobacco leaves. Sci Agric. 2019;76(1):1-9.

23. Pu M, Cui GM, Chen YP, Huang W, Zhao GK, Li RC. Effect of baking conditions in leaf tissue structure of flue-cured tobacco KRK26. Chin Agric Sci Bull. 2013;29(21):188-94.

24. Zhu F, Rao Z, Shen SQ, Sun FS, Ren J, Xiao TJ. Curing characteristics and suitable harvest maturity of fresh flue-cured tobacco leaves in Ankang tobacco growing areas. Agric Sci Technol. 2015;16(4):815-9.

25. McBurney $T$. The relationship between leaf thickness and plant water potential. J Exp Bot. 1992;43(3):327-35.

26. Court WA, Hendel JG. Changes in leaf pigments during senescence of fluecured tobacco. Can J Plant Sci. 1984;64(1):229-32.

27. Zhang LY, Xu ZC, Xian XM, Yang J, Shao HF, Geng ZZ, Wang XJ, Yang WL. Changes of pigment and Total phenol content in leaves of tobacco variety "Honghuadajinyuan" during flue curing. Acta Agric Jiangxi. 2012;24(1):47-9.

28. Guo WM, Yin QS, Song JZ. Research progress on influencing factors of plastid pigment and its degrading products from tobacco. Acta Agric Boreali-Sinica. 2008;23:358-62.

29. Burton HR, Kasperbauer MJ. Changes in chemical composition of tobacco lamina during senescence and curing. 1. Plastid pigments. J Agric Food Chem. 1985;33(5):879-83

30. Huang S, Yang HQ, Zhang FM, Li ZX, Yue Q, Chen WJ, Zhou JH. Effect of baking temperature and humidity change on leaf membrane lipid peroxidation to the different varieties of flue-cured tobacco. J Hunan Agric Univ (Natural Sciences). 2009;35(5):485-92.
31. Yuan WY, Wang XD, Li JY, Cai QS, Zhou H, Jiao XY. Changes of polyphenols and related enzyme activities during flue-cured tobacco growth. Southwest China J Agric Sci. 2017;30(7):1528-32.

32. Wright HE Jr, Burton WW, Berry RC Jr. Soluble browning reaction pigments of aged burley tobacco-II.: the dialysable fraction. Phytochemistry. 1964; 3(4):525-33.

33. Abubakar $Y$, Young $J H$, Johnson WH, Weeks WW. Changes in moisture and chemical composition of flue-cured tobacco during curing. Tob Sci. 2000;44: $51-8$.

34. Wang HZ, Yang HW, Guo HY. Effects of temperature and humidity on starch degradation and related enzyme activities of flue-cured tobacco during flue-curing process. Acta Agron Sin. 2006;32(2):313-6.

35. Moseley JM, Woltz WG, Carr JM, Weybrew JA. The relationship of maturity of the leaf at harvest and certain properties of the cured leaf of flue-cured tobacco. Tob Sci. 1963:7:67-75.

36. Walker EK. Some chemical characteristics of the cured leaves of flue-cured tobacco relative to time of harvest, stalk position and chlorophyll content of the green leaves. Tob Sci. 1968;12:58-65.

37. Liu GS, He YQ, Yang YF, Li J, Gao Q, Peng JM, Liu DS, Mu HY. Effects of combining application of various potassium fertilizers on plastid pigment, carbon-nitrogen metabolism and quality in flue-cured tobacco. Chin Tob Sci. 2013:34(6):49-55.

38. Scheible WR, Gonzalez-Fontes A, Lauerer M, Muller-Rober B, Caboche M, Stitt M. Nitrate acts as a signal to induce organic acid metabolism and repress starch metabolism in tobacco. Plant Cell. 1997;9(5):783-98.

39. Sheen SJ. The distribution of polyphenols, chlorogenic acid oxidase and peroxidase in different plant parts of tobacco, Nicotiana tabacum L. Phytochemistry. 1969:8(10):1839-47.

40. Andersen RA, Chaplin JF, Currin RE, Ford ZT. Plant phenols in flue-cured tobaccos fertilized at different rates. Agron J. 1970;62(3):415-7.

41. Fritig B, Gosse J, Legrand M, Hirth L. Changes in phenylalanine ammonialyase during the hypersensitive reaction of tobacco to TMV. Virology. 1973; 55(2):371-9.

42. Power JF, Willis WO, Grunes DL, Reichman GA. Effect of soil temperature, phosphorus, and plant age on growth analysis of barley 1. Agron J. 1967; 59(3):231-4

43. Brown RH, Cooper RB, Blaser RE. Effects of leaf age on efficiency 1. Crop Sci. 1966;6(2):206-9.

44. Brown GW, Terril TR. Effects of method of harvest on flue-cured tobacco. I. Agronomic factors 1. Agron J. 1972;64(5):619-22

45. Wu YP, Gao YC, Xu ZM, Zhang LX, Zhao LH, Kong GH. Determination of amylose and amylopectin of fresh tobacco by continuous flow method. $J$ Yunnan Univ (Natural Sciences Edition). 2018;40(2):315-20.

\section{Publisher's Note}

Springer Nature remains neutral with regard to jurisdictional claims in published maps and institutional affiliations.

Ready to submit your research? Choose BMC and benefit from

- fast, convenient online submission

- thorough peer review by experienced researchers in your field

- rapid publication on acceptance

- support for research data, including large and complex data types

- gold Open Access which fosters wider collaboration and increased citations

- maximum visibility for your research: over $100 \mathrm{M}$ website views per year

At BMC, research is always in progress.

Learn more biomedcentral.com/submissions 